\title{
LA AUTOBIOGRAFÍA JUVENIL DE JOSÉ CADALSO
}

\author{
FERNANDO DURÁN LÓPEZ \\ Universidad de Cádiz
}

\begin{abstract}
Eń mi edad, que aún no es grande; en mis introducciones, que son buenas, y en el concepto que tengo entre las gentes, me puedo prometer fortuna ${ }^{1}$.

Por lo visto, José Cadalso es un hombre fuera de sitio $^{2}$.
\end{abstract}

El último día de 1773 José Cadalso firmaba una singular autobiografía que permaneció desconocida hasta 1967. La única copia que se ha conservado, de mano de un amanuense, forma parte de un importante manuscrito de Varios que compró Ángel Ferrari en una librería madrileña y que donó a la Biblioteca de la Real Academia de la Historia, donde hoy se custodia (sala 9, segundo armario de Códices, 122); en él también se copiaron una valiosa versión de las Cartas marruecas y los Papeles de campaña ${ }^{3}$. Ferrari se dio cuenta del gran valor de este texto, al que tituló Apuntaciones

\footnotetext{
${ }^{1}$ José CADALSO, Autobiografía - Noches lúgubres, ed. de Manuel Camarero, Madrid, Castalia, 1987, p. 118. Todas las citas de la obra las haré de esta edición señalando sólo la página. El presente artículo es una versión resumida de uno de los capítulos de mi tesis doctoral inédita, La autobiografía moderna en España: nacimiento y evolución (siglo XVIII y principios del XIX), leída en junio de 2001 en la Universidad de Cádiz.

2 Eugenio SUÁreZ-Galbán, «Cadalso frente al género autobiográfico», Revista de literatura, XLV, 90 (1983), pp. 111-125; la cita en p. 122.

${ }_{3}$ «Volumen encuadernado en pasta valenciana, sin portada, una hoja de guarda, cuatro folios en blanco, al principio, 292 folios numerados a lápiz, y una hoja de guarda. El tamaño de los folios es $212 \times 150 \mathrm{~mm}$; caja de escritura $190 \times 112 \mathrm{~mm}$. y 26 renglones por folio. Letra de fines del siglo XVIII", Ángel FERRARI, «Las "Apuntaciones autobiográficas" de José Cadalso en un manuscrito de "Varios"», Boletín de la Real Academia de la Historia, CLXI (1967), pp. 111-143, cita en p. 111. F. AGUILAR PIÑAL describe así el contenido de dicho manuscrito: «Cartas marruecas (fol. 1-165).-Apuntaciones autobiográficas (167r-191 v).-Memorias de la defensa de Gibraltar (fols. 194-208).Poesías políticas (fol. 209-292)» (Bibliografía de autores españoles del siglo XVIII, Madrid, CSIC, 1981-1995); puede leerse un vaciado mucho más minucioso en el citado artículo de Ferrari, pp. 111-113.
}

Rlit, LXIV, 128 (2002), 437-473 
autobiográficas cuando lo dio al público por primera vez ${ }^{4}$. Después se ha reproducido en tres ocasiones más, siempre en compañía de otras obras cadalsianas, debido a su pequeño tamaño ${ }^{5}$.

La existencia de esta obra, que se creía perdida, se conocía por ser uno de los manuscritos que menciona Cadalso en una célebre carta de abril o mayo de 1775 a Meléndez Valdés (n. ${ }^{\circ} 56$ del citado Epistolario). En ella anuncia a su amigo el envío de varios de sus papeles, puesto que planeaba marchar a la guerra, para que los ocultase de miradas indiscretas y quedase como su heredero si muriera en el frente. En la lista de las obras remitidas el número siete es: «Memoria de los acontecimientos más particulares de mi vida. Guárdelo Vmd. para hacer uso de él para su gobierno en el mundo. Por ningún término publique Vmd. los nombres ni lugares ni tiempos que cito. Sobre esto encargo su buen corazón, amor al prójimo y fidelidad a su amigo» (ibíd., p. 103). Y un poco más adelante se refiere de pasada otra vez a esa obra, llamándola Compendio de mi vida.

La obra se divide en cuatro fragmentos, de distinta fecha y hechura estilística: el primero y más extenso es la autobiografía propiamente dicha, que se terminó de redactar, como reza en su renglón final, «hoy, último del año de 1773»; está dividido en apartados de desigual tamaño, que se encabezan con epígrafes alusivos a la materia tratada. El segundo fragmento se redactó a principios de 1778 , según datación indirecta por su contenido, que comprende hechos ocurridos entre septiembre de 1774 y febrero de 1778. El tercer fragmento narra sucesos fechables entre el 17 de febrero de 1778 y mayo de 1779. Hay, por fin, una «Nota» final que parece ser de 1781, cuando ya está en el frente de Gibraltar, poco antes de su muerte. Estas secciones finales agrupan hechos deshilvanados, anotados con precipitación y con menor rigor literario que el cuerpo central. Camarero explica esta disparidad entre el primer y los demás fragmentos del modo siguiente:

\footnotetext{
${ }^{4}$ Art. cit., pp. $115-143$.

${ }^{5}$ Nigel Glendinning y Nicole Harrison la incluyeron en el volumen Escritos autobiográficos y epistolario, Londres, Tamesis Books, 1979, pp. 3-32, donde elaboraron el primer estudio del texto y lo enmarcaron entre los otros documentos personales conocidos del escritor gaditano, ochenta y dos cartas, dando a la autobiografía el título de Memoria de los acontecimientos más particulares de mi vida (1773) y sus continuaciones entre 1774 y 1778; 1778 y 1779; 1779 y 1780. La siguiente edición es la citada de Camarero en colección «Clásicos Castalia» (pp. 87-123), junto a las Noches lúgubres. Esta misma combinación, que puede justificarse en razón de que las Noches lúgubres se han venido considerando una autobiografía encubierta, fue seguida en la última edición de la que tengo noticia: Las noches lúgubres, seguidas de la Memoria de los acontecimientos más particulares de mi vida, Madrid, Los Libros de Autor, 1993, pp. 71-111; se trata de una edición de bibliófilo, con abundantes ilustraciones, pero sin rigor crítico, sin indicar editor y $\sin$ incluir las adiciones del texto posteriores a 1773 .
} 
Me pregunto si estas últimas páginas las escribió como addenda, o serían simplemente un recordatorio para una redacción posterior; aun se podría conjeturar que la verdadera continuación de la Memoria fuera ese Diario reservado que cita algunas veces, y no estas anotaciones cuasi telegráficas. Dudo, en fin, si Cadalso dio por conclusa su obra cuando, junto con otros manuscritos, remitió en la primavera de 1775 a Meléndez lo que se ha considerado la primera parte. Por eso he dado al conjunto el título de Autobiografía y lo he dividido en dos partes bien diferenciadas: la primera es la Memoria de los acontecimientos más particulares de mi vida y corresponde al primer fragmento; la segunda, que denomino Apuntaciones autobiográficas, acogiéndome a lo que dice el propio autor ${ }^{6}$, corresponde a los fragmentos restantes y la considero inacabada, como un borrador, unas apuntaciones rápidas para una redacción posterior (ed. cit., p. 28).

Por su parte, Glendinning y Harrison creen que la primera parte y las adiciones responden a motivos diferentes, ya que en la primera:

[...] Cadalso miraba hacia atrás, describiendo lo ya pasado, y contemplando su vida y su carrera desde la perspectiva del hombre apartado del mundo y, según sus propias palabras, «bien desengañado de corte, amigos y pretensiones, y entregado a mis libros». En las continuaciones, en cambio, piensa de vez en cuando en el presente, e incluso en el porvenir. [...] Las continuaciones, por lo tanto, no se distancian de la vida como la Memoria, y no parten de un punto de vista tan pesimista. Corresponden a nuevos momentos de vitalidad, nuevas ambiciones y frustraciones, nuevos motivos para salir adelante (ob. cit., p. IX).

Estas observaciones no dejan de ser una obviedad, pero la discusión que plantean en torno a la naturaleza dispar de las partes finales de esta autobiografía expresa una extrañeza propia de quienes no están familiarizados con el género autobiográfico. En las autobiografías inéditas o concebidas sólo para uso privado en esta época, es habitualísimo hallar finales erráticos, con adiciones y actualizaciones, notas finales, secuencias diarísticas y apuntes sueltos sin tensión narrativa. Se trata del eterno desfase entre una actividad literaria que aspira a totalizar la vida y una vida que no se deja totalizar; la escritura autobiográfica es finita y después de ella la existencia sigue fluyendo al menos un trecho más, el autor se afana por atraparla con nuevas dentelladas, pero el aliento literario desfallece. Hay muchísimos casos iguales: esto tiene que ver con el género, no con el autor.

\section{El ENIGMA DE CADALSO}

El escrito carece de pacto autobiográfico: no hay prólogo ni comentario alguno sobre los motivos y las circunstancias de su escritura, así que hemos de reconstruir sus intenciones a partir de indicios externos. En la

\footnotetext{
${ }^{6}$ «Más adelante pondré en estas apuntaciones mi proyecto».
} 
citada carta a Meléndez Valdés de 1775 hace hincapié en una instrucción: que bajo ningún concepto divulgue el contenido. El militar tenía muy claro el carácter secreto y personal de su obra, que no estaba destinada para la imprenta. Ésta es la primera idea que debe acompañar el comentario de la obra, y que a veces tiende a olvidarse: su condición estrictamente privada y, más aún, podemos decir que clandestina, ya que el tratamiento que recibe un personaje tan poderoso como el conde de Aranda haría su difusión muy arriesgada para el autor ${ }^{7}$. Como en los otros casos conocidos (los de José Antonio de Armona, Francisco de Saavedra, Antonio Porlier, etc. ${ }^{8}$ ), la autobiografía moderna nace en la reclusión del gabinete de trabajo, como obra consagrada para el fuero privado, como legado moral a familiares o para fieles amigos: la privacidad se constituye en la condición básica que garantiza poder darle un contenido confesional y expresarse con libertad ${ }^{9}$. Hablando del género autobiográfico con perspectiva histórica, cosa que por

${ }^{7}$ Esto no obsta para que tuviera alguna divulgación, como resalta Gabriel SÁNCHEZ ESPINOSA: «nos consta una cierta difusión manuscrita del texto. Prueba de ella es la inclusión de las memorias entre los manuscritos confiados por Cadalso a Meléndez Valdés en 1775» (intr. a Las memorias de José Nicolás de Azara (ms. 20121 de la BNM). Estudio y edición del texto, Frankfurt, Peter Lang, 1994, p. 186). Esto no invalida lo dicho, ya que esa divulgación sería también privadísima.

${ }^{8}$ Los detalles bibliográficos y del contenido sobre todos estos autobiógrafos y sobre los demás aludidos en este artículo pueden leerse en mi Catálogo citado en la nota 13 y en la tesis doctoral que menciono en la nota 1 .

${ }^{9}$ La autobiografía no es el único escrito personal de Cadalso y todos ellos se envolvieron con idéntico manto semiclandestino. Los autobiógrafos dieciochescos suelen operar sobre un fermento de epistolarios, diarios y escritos personales que mantienen diversas relaciones con sus autobiografías propiamente dichas. Cadalso, a lo largo de su Memoria de los acontecimientos más particulares remite a otros escritos que iban a complementarla o a seguir digresiones que consideraba inadecuadas en la obra principal. Así, menciona una lista de veintitrés semblanzas de todas las personas importantes de su vida, una de ellas María Ignacia Ibáñez, de cuyos felices amores y trágica muerte dice en cierto momento que iba a formar un escrito separado. También escribió un Diario reservado, al que igualmente remite en alguna ocasión, y que sin duda contenía datos valiosísimos de su vida privada e íntima, pero cuyo mismo nombre proclama su condición secreta. No queda rastro de él, pero sí se conservan sus Papeles de la campaña o Diario crítico del sitio de Gibraltar, cuya única copia conocida ocupa los folios 194208 del mismo volumen del que se sacó la autobiografía. Su editor moderno sostiene que, contra lo que se ha conjeturado, los Papeles no corresponden al Diario crítico que no se conserva, sino que es obra distinta. Los Papeles, por su escueta redacción, brevedad y un cierto fragmentarismo estarían en una línea diferente: "por el valor autobiográfico de las dos primeras partes puede considerarse el manuscrito como ampliación del final de las Apuntaciones autobiográficas, a partir del párrafo que comienza: "Llegué a San Roque y después de algún tiempo me hice cargo de Gibraltar, su situación..."”, José Gella IturRiaga, «Los Papeles de campaña de Cadalso en un manuscrito de Varios», Boletín de la Real Academia de la Historia, CLXXIII, 2 (1976), p. 230. Es un escrito escasamente personal, aunque sí brilla la habitual penetración y sentido crítico del autor. 
cierto no siempre hacen los especialistas en este tipo de escritura, hay que subrayar que todos los casos españoles de esta etapa inicial de la autobiografía moderna indican que ésta se desarrolla como escritura privada durante mucho tiempo antes de que madure como género admisible en el ámbito público, lo que podría sin duda documentarse en otras literaturas. Dicho de otro modo, el individuo moderno madura antes que la sociedad moderna.

Por otra parte, y ésta es una frase enigmática, Cadalso escribe a Meléndez que haga uso de su manuscrito «para su gobierno en el mundo» ${ }^{10}$. Poco más podemos conjeturar sobre sus intenciones a partir de sus declaraciones explícitas: el resto del análisis atañe a interpretaciones del texto, que hasta la fecha han sido tan variadas como contradictorias. Dada la importancia de Cadalso en las letras de la Ilustración española, la complejidad de su figura y lo original y anómalo de su aportación al corpus de la autobiografía hispana, no es asombroso que las Apuntaciones hayan dado lugar a un debate crítico especialmente rico. Salvando el caso de Torres Villarroel, ninguna otra pieza autobiográfica del XVIII ha suscitado tanto interés. En efecto, la aparición del texto en 1967 levantó la lógica curiosidad, ya que el hallazgo de un escrito autobiográfico desconocido de un escritor de tanta nombradía no es algo habitual: este opúsculo modificó y amplió el conocimiento disponible de la biografía cadalsiana ${ }^{11}$. Aun así, el documento no es tan valioso por los datos que aporta, que en pocos casos modifican lo que ya se sabía, como por su valor psicológico, para penetrar en los entresijos de la personalidad y contradicciones del escritor ${ }^{12}$. A ese fin se orienta casi todo el esfuerzo de los investigadores que han intentado desentrañar esta obra ${ }^{13}$.

${ }_{10}$ Volveré sobre esta frase al final de este artículo.

1 Cf. Manuel CAMARERo, «A vueltas con la biografía de Cadalso», Ínsula, 423 (1982), pp. 3 y 5.

12 Valgan dos ejemplos de la biografía de Nigel GLENDINNING (Vida y obra de Cadalso, Madrid, Gredos, 1962), anterior a la recuperación del manuscrito: en ella se malinterpretan las relaciones entre el escritor y su padre, sin sospechar la amargura y el resentimiento que anidaban en ellas; no se advierte el terrible conflicto entre ambos por la elección de carrera ni las auténticas razones de su segunda estancia en Inglaterra, presentada como otro viaje de estudios proporcionado por un padre benévolo que habría estado muy cerca de su hijo hasta su muerte. Igualmente, no se menciona ni una sola vez el nombre de Oquendo, el amigo traidor, el personaje más intensamente evocado en la autobiografía y causante de una grave crisis emocional.

13 Además de las introducciones de Glendinning y de Camarero a sus ediciones, existen tres artículos monográficos sobre esta obra: María EMBEITA, «Cadalso y el acto autobiográfico», Cuadernos hispanoamericanos, 389 (1982), pp. 322-326; Philip DEACON, «José de Cadalso, una personalidad esquiva», ibídem, pp. 327-330; y Eugenio SUÁREZGALBÁN, art. cit. Cabe destacar también el espacio que le dedican obras generales sobre la autobiografía dieciochesca española: Monroe Z. HAFTER, "Two perspectives on self in Spanish autobiography (1743-1845)», Dieciocho, 16, 1-2 (1993), pp. 77-93; Gabriel 
Se ha insistido en que se trata de un texto misterioso, que Cadalso se escurre entre sus páginas y que al lector le queda una cierta frustración tras leerlo. Suárez-Galbán afirma: «Una nota de rareza, un aura de misterio, y hasta cierto carácter enigmático, permean este texto cadalsiano en su conjunto» (art. cit., p. 113). Y Philip Deacon, por su parte, considera que «La impresión que se saca al leer estos textos [...] es que la personalidad del corresponsal no cuadra con la del biógrafo. El lector se queda con la sensación de no haber conseguido conocer al auténtico Cadalso. Es como si el autor no quisiera revelarse. [...] Recibimos la impresión de que Cadalso está creando una máscara literaria» (art. cit., p. 328). Incluso su primer editor, Ángel Ferrari, se desconcierta ante la dificultad de emitir un juicio sobre la aportación histórica del texto - único eje interpretativo que parece interesarle - y acaba reclamando una lectura psicológica que explique la rotundidad de los juicios negativos de Cadalso sobre asuntos de su tiempo, sin dejar claro a qué se refiere (cf. art. cit., p. 114).

Esta extendida perplejidad está muy fundada. Cadalso es un escritor incómodo para las clasificaciones literarias, y no sólo en el terreno de la autobiografía. Tanto su personalidad como su valía son demasiado pronunciadas como para dejarse ajustar con soltura en las ideas preconcebidas que se tienen de la literatura y el pensamiento de su época, que sin embargo él representa en una de sus cotas más altas. De ahí la enconada disputa sobre su romanticismo o su neoclasicismo; de ahí también las divergentes opiniones suscitadas por las Cartas marruecas, las Noches lúgubres, sus poesías y sus otros escritos. No obstante, estas extrañezas no pueden disculparnos de buscar una explicación que no sea meramente subjetiva, aun asumiendo los riesgos de errar en el análisis. A mi juicio, hay que tomar en cuenta ciertos aspectos de la memoria cadalsiana que no han sido suficientemente comprendidos, y que pienso ayudan a explicar las dudas que deja sin resolver esta autobiografía. Es preciso por ello analizar la discusión crítica que se ha generado, para ver a qué diferentes resultados han conducido los intentos de resolver el mentado «enigma» cadalsiano.

\section{MODELOS Y MÓVILES AUTOBIOGRÁFICOS}

La primera duda que ha suscitado la obra es la de sus posibles modelos literarios. Ésta es una pregunta que aparece cada vez que se estudia un texto autobiográfico español anterior a la segunda mitad del XIX: el escaso conocimiento que en general se tiene de la materia hace que los estudio-

SÁNCHEZ ESPINOSA, ob. cit., pp. 182-186; Fernando DURÁN LÓPEZ, Catálogo comentado de la autobiografía española (siglos XVIII y XIX), Madrid, Ollero \& Ramos, 1997, n. ${ }^{\circ} 86$. 
sos no sepan bien cómo encuadrar las piezas a que ocasionalmente se acercan: a veces dan palos de ciego intentando aproximarlas a territorios mejor conocidos y más prestigiosos, o por el contrario, establecen genealogías literarias improbables y rebuscadas. Con Cadalso la cosa se complica porque se trata de un texto difícil, que no admite ser explicado en virtud de un mero principio de imitación. El establecimiento de sus modelos o influencias no es, sin embargo, una cuestión erudita de importancia menor, sino que atañe de lleno a las interpretaciones que se den al contenido de la obra y a su adscripción a una u otra modalidad autobiográfica.

Ángel Ferrari señala sin dar argumentos que son «...las "Memorias de mi vida" o las "Apuntaciones", [...] tan breve como importante obra, una de las más sobresalientes en nuestra literatura, entre las de su género» (art. cit., p. 113), que es como no decir nada. Los siguientes editores, Glendinning y Harrison, elaboran un estudio más completo, según el cual el escrito de Cadalso aparece en un momento de «creciente interés por las obras de tipo autobiográfico. En España se nota también un sensible aumento en su número en la segunda mitad del siglo XVIII respecto a la primera» (ob. cit., p. X). Respecto a las posibles fuentes, consideran todos los modelos de autobiografía posibles, empezando por las vidas de soldados del Siglo de Oro y sus cercanos parientes, las vidas ficticias de la picaresca:

En primer lugar, sería interesante saber si Cadalso conocía algunas de las memorias escritas por soldados españoles en los siglos XVI y XVII. Es poco probable [...] [porque Contreras, Duque de Estrada y otros estaban inéditos]. Cadalso hubiera podido leer, sin embargo, la [...] Vida de García de Paredes, y también, claro está, las novelas picarescas de la vida militar, como la Vida de Estebanillo González, que también podría ser parcialmente autobiográfica. Algo de este género hay en la Memoria de Cadalso. El lance con el marqués de Tabuérniga durante la campaña de Portugal, y el escarceo más adelante con los espías del conde de Aranda, recuerdan las bravatas de tales Vidas. También la estructura de las Memorias de soldados suele ceñirse a la temática de los altibajos de la fortuna, como lo hace la Vida de Cadalso ( $o b$. cit., p. XI).

Rechazan la posibilidad de que el gaditano pudiera haberse inspirado en las autobiografías religiosas o en las memorias de tipo histórico-político, aunque este último caso admiten que es «más cercano a Cadalso» (p. XII). Otra alternativa la facilitan las autobiografías que muestran las carreras, orígenes y méritos de escritores, como las de Cardano o Torres Villarroel, pero desechan esta idea porque, según Glendinning y Harrison, Cadalso no sigue un modelo de autobiografía triunfal, sino que invierte el relato de éxito en relato de fracaso. La conclusión, aunque no se formula explícitamente, es que el modelo más afín son las obras picarescas y autobiografías de soldados, por la presunta disposición del argumento en alti- 
bajos de la fortuna, por ciertos episodios broncos que recuerdan las aventuras que proliferan en aquéllas y por el tono desengañado ${ }^{14}$.

María Embeita, en cambio, aunque en cierto momento relaciona la penuria de hidalgo empobrecido de Cadalso con el escudero del Lazarillo de Tormes (art. cit., p. 326), vincula su autobiografía con el modelo de Rousseau - no es obviamente una influencia directa, ya que la obra de Cadalso es anterior- para considerarla una plena autobiografía moderna. La interpretación de Eugenio Suárez-Galbán va en idéntica línea, que es la que este crítico había desarrollado previamente sobre Torres Villarroel: tanto el gaditano como el salmantino serían precursores de la autobiografía moderna rousseauniana ${ }^{15}$. Suárez-Galbán a continuación se pregunta si Cadalso aporta algo a ese naciente género o sólo sigue una moda: «¿Qué significa el que, justo en el momento en que está naciendo la autobiografía moderna, este soldado solitario, taciturno y reservado, sienta la tentación - por breve que sea- de adentrarse en este tipo de literatura?» (art. cit., p. 113). Para Suárez-Galbán, su actitud ante la escritura personal es incómoda y angustiosa. De ahí el uso de Memoria y no Memorias, y el título alternativo Compendio..., que indica que Cadalso tenía presente la necesidad de realizar un escrito breve, «una primera prueba de reticencia y parquedad» (ibíd.). Conclusión: «Cadalso no se sentía totalmente a gusto con un género que, de una forma u otra, tiende hacia la autorrevelación» (ibíd., p. 114). Eso diferenciaría al gaditano de la tradición confesional de la autobiografía moderna, sin realizar la descripción del yo que el crítico ve en Torres, Rousseau o Amiel, pero también sin caer en el jactancioso recuento de éxitos que vemos en el salmantino, o en la crónica de hechos exteriores. El carácter paradójico de esta autobiografía estaría en esa voluntad de contar su vida, pero al mismo tiempo emplear un estilo casi anónimo que se oculta tras la reticencia y el desengaño. Esta contradicción no se resuelve: el hombre moderno es fruto de ella y Cadalso expresa así su condición de hombre contradictorio y fuera de sitio.

\footnotetext{
${ }^{14} \mathrm{El}$ artículo de Deacon recoge estas sugerencias de manera menos conjetural: «La narración pertenece a una larga serie de autobiografías de soldados como las de Alonso de Contreras o Diego Duque de Estrada, y a veces la Memoria recuerda el género en el modo de estructurar el texto de acuerdo con los altibajos de la fortuna. Pero si bien muchas de las autobiografías anteriores pertenecen a una línea de historias triunfantes, la de Cadalso, al menos en su mayor parte, relata sobre todo una falta de éxito. El autor se concentra en un momento de su vida en que está "bien desengañado de Corte, amigos y pretensiones, y entregado a mis libros". Está ansioso por mostrar que la vida no ha sido justa con él [...]», art. cit., p. 328 .

15 «la vida, las memorias y los escritos autobiográficos cadalsianos quedan claramente inscritos dentro del periodo clave de la gestación del género autobiográfico en su vertiente moderna», art. cit., p. 111. El libro fundamental de SUÁREZ-GALBÁN sobre esta materia es La Vida de Torres Villarroel, literatura antipicaresca, autobiografía burguesa, Carolina del Norte (EE. UU.), University of North Carolina, Estudios de Hispanófila, 1975.
} 


\begin{abstract}
La permanente insatisfacción cadalsiana, pues, difícilmente se explica sin más como tópico de época, o contagio de ambiente. La verdad autobiográfica cadalsiana parece ser otra, parece una vez más trascender la cuestión de época y su transición de un tipo de visión cósmica a otra. Parece más bien que don José, al igual que Villarroel y Rousseau, sentía ya esa angustia moderna que, hasta la fecha caracteriza al género autobiográfico en su más profunda y valiosa manifestación, al menos desde una perspectiva metafísica. Por encima de romántico, Cadalso, el Cadalso autobiográfico, es, como nosotros, el hombre que se siente fuera de sitio en un mundo y en una existencia cuyos valores e ideales son siempre cuestionables, engendrando así la constante de la contradicción (art. cit., p. 124).
\end{abstract}

Manuel Camarero, retomando las insinuaciones de Glendinning y Harrison, es quien más firmemente ha querido relacionar la autobiografía de Cadalso con las vidas de pícaros, en un apartado que titula «La "Memoria" y la técnica picaresca» (ed. cit., pp. 30-31). Habría diferentes episodios argumentales que evocan la figura del pícaro literario ${ }^{16}$, igual que el énfasis puesto en las desgracias de salud y de fortuna y en la queja continua, pero no, como dicen Glendinning y Harrison, por los altibajos de la fortuna, sino «para destacar su mala suerte, su ruin dicha, lo mismo que Lázaro» (ibíd., p. 33). En resumen: «La Memoria [...] cuenta [...] lo mismo que Lázaro de Tormes: "sus fortunas y adversidades"; pero no con el cinismo que caracteriza al pícaro [...], sino con la amargura - un poco paranoica - de quien se siente víctima; un hombre de bien cuya formación intelectual, cuyo talento y virtudes, no son comprendidos ni, sobre todo, recompensados como merecen» (ibíd., p. 34).

Por último, Gabriel Sánchez Espinosa rechaza con contundencia tanto la opinión de que la de Cadalso sea una autobiografía vinculable a la de Rousseau como el criterio de que refleje el modelo picaresco ( $\ll$ Ni Cadalso es un pícaro ni su vida es una vida picaresca», ob. cit., p. 185). En cambio le cuadra mejor la creencia de Glendinning y Harrison en una influencia de las memorias de soldados, no como aportación directa, sino como «cierta identidad en la materia» (ibíd., p. 183), salvando las distancias entre la movida actividad bélica del XVI y XVII y la más tranquila y rutinaria del XVIII:

16 Por ejemplo, cuando el gaditano, para lograr ser soldado, hace creer a su padre que pretendía hacerse jesuita: «...Cadalso utiliza una técnica frecuente en la novela picaresca, que consiste en que el pícaro finge una situación para provocar que el amo la transforme en otra opuesta que, en realidad, le favorezca más, aunque al final el protagonista termine escarmentado del engaño» (ed. cit., pp. 30-31). La reacción cuando el padre frustra su treta mandándolo a Londres consiste en hacer un chiste cínico e irreverente, que a Camarero también le parece propio de un pícaro: «Cadalso - como personaje de la Memoria - reacciona alguna vez como los protagonistas de las novelas picarescas, y aún se verá que hasta es posible establecer cierto paralelismo entre Lázaro de Tormes y él» (ibid., p. 31). 
[...] las memorias de Cadalso desarrollan los diferentes motivos recurrentes del discurso sobre sí mismo realizado por militares profesionales sin título durante el último siglo del Antiguo Régimen: las diferentes vivencias de la camaradería militar [...], la esperanza de una coronelía con otras ambiciones y planes privados de ascensos y distinciones [...], la búsqueda de un protector [...], los esfuerzos del propio coronel en la corte por hacer avanzar la carrera del memorialista, las relaciones entre oficiales con mando en tropa [...] y oficiales de estado mayor [...], los problemas económicos, y las distracciones en los espacios interminables de la vida militar no ocupados por el servicio [...] (ibíd., pp. $183-184)^{17}$.

Es claro que se perfilan dos lecturas antagónicas. La primera asegura que la autobiografía de Cadalso se ha de relacionar con relatos de tipo aventurero, es decir, narraciones más o menos movidas que giran en torno a la fuerza de su argumento, centradas en la vida externa de la carrera militar y las ambiciones mundanas, así como en los altibajos de la fortuna; se remite para ello a las vidas picarescas o a las memorias de soldados, o a ambas a la vez sin distinción. Ésta es la posición de Glendinning y Harrison, Deacon, Camarero y Sánchez Espinosa. La segunda tesis sostiene, en cambio, que el opúsculo cadalsiano es una autobiografía confesional, de análisis introspectivo por parte de un sujeto que explora su personalidad, sometido a dudas y a angustias, es decir, una autobiografía moderna que se puede asociar en alguna manera al formato rousseauniano, por más diferencias que haya entre Cadalso y el ginebrino. Ésta es la opinión de Embeita, Suárez-Galbán y la mía propia. Las dos posturas extremas pueden contrastarse en estas dos sentencias:

[...] el texto de las Apuntaciones corresponde plenamente a la definición de «autobiografía», es decir, al texto de una narración cuyo núcleo central de interés no estriba en un complejo de acontecimientos históricos en los que el autor [...] participa como actor o testigo, sino en su historia personal. [...] Respeta a un nivel global el orden cronológico dentro de una secuencia temporal lógica coherente, que corresponde al desarrollo psicológico del individuo [...]. El discurso oscila entre dos polos: la memoria y la conciencia de sí (Embeita, art. cit., pp. 322-323).

[...] es claramente unas memorias, no una autobiografía. Su tema es la carrera de Cadalso, su vida social, el hombre público. No nos hallamos de ningún modo ante una autobiografía de corte y tono rousseauniano, ante una confesión íntima, como afirma María Embeita [...]. Cadalso pretende hacer la memoria de su carrera civil. Consiguientemente, el texto recibe su articulación a partir de los factores y las etapas de ésta: origen familiar, educación, toma de estado militar, crónica de sus sucesos en relación con el presidente Aranda y registro de su vida en el servicio (Sánchez Espinosa, ob. cit., pp. 182-183).

17 De cada uno de los puntos enumerados el crítico ofrece alguna muestra, no siempre muy convincente: para ilustrar la camaradería militar, por ejemplo, cita el episodio de la pelea tabernaria de Cadalso con el marqués de Tabuérniga, que no parece muy apropiado para el caso. 
A mi juicio, las opiniones que relacionan la autobiografía de Cadalso con la picaresca o las memorias militares parten de una lectura parcial del texto, del que seleccionan unos pocos elementos que quedan descontextualizados. Con la misma fuerza argumental podría sostenerse que la obra cadalsiana es una vida literaria ${ }^{18}$, porque hay algunas noticias sobre sus escritos, o una autobiografía amorosa, porque también hay pasajes para corroborarlo. En conjunto, los Apuntes resultan erráticos y desiguales si no se encuentra cuál es el eje que les da coherencia y unidad: ese eje no es otro, en mi opinión, que la exploración psicológica que efectúa de su vida el autor, dentro -eso sí- de unos estrictos límites que no resisten la comparación con el ejemplo rousseauniano.

Para defender esta lectura es preciso partir de las cuestiones más controvertidas en los análisis citados: determinar cuál es el objeto sobre el que recae el evidente pesimismo de Cadalso, es decir, discutir el valor que posee en la obra la adversa fortuna; estudiar el estilo de la prosa cadalsiana en esta autobiografía y sus implicaciones; y aclarar el sentido de los episodios que se han querido relacionar con otros modelos autobiográficos, explicándolos en el marco global del texto, lo que implica construir una descripción completa de todas sus secuencias narrativas, para ver el peso real de cada una en el conjunto.

\section{¿FRUSTRACIÓN SOCIAL O FRUSTRACIÓN MORAL? LA ADVERSA FORTUNA}

Todos los críticos formulan una impresión semejante respecto al contenido de la Memoria cadalsiana: autobiografía pesimista, que se ensaña en el lado negativo de la vida del autor, creando una pose de víctima. Hay total unanimidad - a la que me sumo - en destacar ese registro amargo y quejumbroso, lo que no obsta para que también haya grandes divergencias en su interpretación.

Glendinning y Harrison creen que la autobiografía de Cadalso es un relato de triunfo burgués a la inversa: «Si muchas Memorias sirven para documentar los éxitos del autor, permitiéndonos seguirle los pasos hasta

\footnotetext{
${ }^{18}$ Con vida literaria me refiero a un tipo de escrito autobiográfico que prolifera entre los escritores del XVIII y comienzos del XIX, en el cual un hombre de letras expone, casi siempre de manera vanidosa e impersonal, a menudo en tercera persona, su formación, sus ideas y la historia de sus tareas literarias y demás actividades propias del amplio perfil del intelectual ilustrado (sociabilidad erudita, viajes, servicios al gobierno, etc.). Es una escritura inspirada en las bio-bibliografías de escritores que pone de moda la nueva historia literaria que cobra auge en el XVIII, y a mi juicio de ella sale, en gran medida, lo que luego será la auténtica autobiografía moderna. En España hay más de una decena de textos semejantes en el siglo largo que va desde el del deán Manuel Martí hasta el del deán Manuel López Cepero. Estudio en detalle esta modalidad autobiográfica en la segunda parte de mi citada tesis doctoral.
} 
las posiciones de poder o influencia, las de Cadalso son [...] un success story vuelto al revés: la historia de una falta de éxito, y un examen de las buenas cualidades que tiene, y que no logran el aprecio que se merecen en la sociedad de sus tiempos» (ed. cit., pp. XII-XIII). Partiendo de una posición acomodada, su vida sería un continuo ir de frustración en frustración, que Cadalso relata con victimismo y con ironía, recreándose en ellas y prescindiendo de todo lo positivo que también hubo en su vida mediante una selección negativa de la materia. Por razón que pudiera haber en sus quejas, Glendinning y Harrison sentencian, por último, que «a veces las exagera, pintando las cosas más negras de lo que eran» (ibíd., p. XIV) ${ }^{19}$. Deacon insiste en esa frustración social: «Cadalso se presenta a sí mismo como víctima. Es consciente de su privilegiada posición social y, sin embargo, sus esperanzas de avanzar se ven frustradas constantemente por aquellos que presenta como faltos de la inteligencia, virtudes y buenas cualidades que posee él mismo» (art. cit., p. 328).

Suárez-Galbán, por su parte, afirma que hay en Cadalso una manía persecutoria, un victimismo que, en su caso, no persigue captar la simpatía del lector como en Torres Villarroel, sino que responde a una íntima desilusión. La angustia y el pesimismo son crecientes: Cadalso recurre al

\footnotetext{
${ }^{19}$ En la biografía de Glendinning sobre Cadalso de 1962, cuando aún no se conocía el manuscrito autobiográfico, el erudito británico menospreciaba aún más las quejas del gaditano como un injustificado acceso de pesimismo que le acometió en el último tramo de su vida, al tiempo que el biógrafo idealiza su infancia y presenta las relaciones con su padre como armónicas y apacibles. «Cadalso, en sus últimos años, se refería con nostalgia a la felicidad y buena fortuna que presidieron sus primeros pasos en la vida. "Nací rico", declara en su epitafio latino; y, en uno de sus poemas, afirma que su infancia transcurrió "alegre como sueño". Parece que, tan sólo al final, cuando su vida estaba próxima a terminar, cuando contemplaba el pasado desde un punto de vista pesimista, llegó a creer que la mala fortuna le había perseguido desde un principio, y hasta se atrevió a hablar de "la desgracia que me acompaña desde la niñez" y a referirse a sí mismo como a "quien desde niño tuvo lances de hombre, y de joven, desengaños de viejo". Por lo que puede apreciarse, en la vida de Cadalso no se ve señal de desgracia ni de trastorno emocional alguno hasta que las circunstancias, muchos años después, en 1768 [con su destierro a Zaragoza], le depararon uno, súbitamente y de modo inesperado. El transcurso de su vida hasta entonces fue relativamente normal, y las suposiciones de algunos críticos y biógrafos que han querido ver en Cadalso desde sus primeros tiempos un alma solitaria y romántica, son infundadas y desorientadoras» (ob. cit., p. 105). El testimonio de la autobiografía, sin embargo, hace adelantar ese acceso de pesimismo hasta al menos 1773 , porque en ella es evidente una lectura fatalista de su vida y unas tormentosas relaciones con su padre que enturbian esa presunta felicidad infantil. En 1979 Glendinning, junto con Harrison, sigue manteniendo la opinión de que Cadalso exagera sus males, pero ya no puede negar que el pesimismo es una actitud temprana y muy arraigada en su carácter: «El Compendio de la vida de Cadalso es [...] la obra de un hombre que tiene propensión a sentirse víctima, lo mismo que Tediato en las Noches lúgubres [...]. No es difícil comprender por qué le parecía que su vida era así. Redactaba el primer trozo de sus Memorias cuando se sentía aislado y postergado en su carrera» (ed. cit., p. XIII).
} 
humor, pero luego se va imponiendo un tono pesimista que «acabará por absorber todo» (art. cit., p. 115). El crítico busca una explicación a esa zozobra íntima cuya causa - dice- no está clara y trata de acceder a ella entendiendo el texto como «de clave sicológica» (ibíd., p. 117), a partir de ciertas preocupaciones recurrentes que no se pueden reducir a un problema circunstancial de su vida o al espíritu del Romanticismo (ésa es la teoría de Sebold): la muerte temprana de su madre, la ausencia de su padre y su educación en el extranjero, que le hizo sentirse foráneo en su propia patria; su insatisfacción sobre su carrera militar, destino que nunca acabó de convencerle; su desasosegante búsqueda de la amistad y su idealización del retiro en el campo, que contrasta con su vida cortesana.

Camarero, como Glendinning y Harrison, opina que el gaditano literaturiza su vida en la autobiografía, llevado por su «tendencia a la hipérbole» (ed. cit., p. 33). Así, espiga las muchas referencias dispersas sobre la pobreza y la enfermedad para concluir que «el autor hiperbolizaba de este modo unas situaciones ya de por sí desgraciadas, para producir mayor conmiseración en el lector» (ibíd., p. 30). Igualmente destaca que elabora páginas tan sombrías cuando se encuentra en Salamanca, rodeado de un círculo de amigos escritores con quienes desarrolla una intensa amistad. «La Memoria parece, pues, más literaria que realmente autobiográfica; cuenta sucesos reales, pero barnizados retóricamente» (ibíd., p. 34). Al contrario que Suárez-Galbán, Camarero cree que esta obsesión se justifica por su ambición social:

Conviene dilucidar, si es posible, hasta qué punto hay una motivación puramente social en sus deseos de medrar y hasta qué punto esos deseos no son, en el fondo, económicos [...]. ¿Qué es, entonces, la fortuna para Cadalso? ¿Quizás una mezcla de vanidad aristocrática y protagonismo político? Probablemente sí, porque ese dandy — como le llama Sebold- que tanto gustaba del ambiente cortesano, aunque renegase de él cuando las circunstancias le eran adversas y entonces acudiese al tópico del «menosprecio de corte y alabanza de aldea», ensalzando una naturaleza bucólica y artificial (ni siquiera ideal), parece dar más importancia a su posición social y a sus deseos de influir en la política del país, que a medrar económicamente para retirarse a un lugar aislado e idílico, cuya existencia ponía en duda y más en España. [...] Se comprende así mejor su frustración progresiva, porque ve rechazadas una y otra vez sus solicitudes de ascenso en el escalafón militar y desatendidas sus propuestas militares y políticas (ibíd., pp. 35-36).

En una línea parecida interpreta este pesimismo Sánchez Espinosa, que entiende que Cadalso escribe la historia de su carrera profesional como soldado y cortesano, convirtiéndola en la narración de su fracaso como cliente político del conde de Aranda: «Las memorias de Cadalso son la crónica de una frustración profesional, con sus vertientes militar y literaria, que deviene en una profunda frustración personal» (ob. cit., p. 184).

Volvemos, en resumen, a tener dos lecturas contrapuestas: en primer 
lugar, el pesimismo se interpreta como una frustración social ante el fracaso en hacerse un lugar en la corte, que sume a Cadalso en un hondo decaimiento moral por no poder conseguir los objetivos mundanos que corresponden a sus méritos y a su origen. Quienes piensan que esta obra son unas memorias profesionales inciden, de esta forma, en los hechos concretos que mueven a Cadalso a ver su vida tan negra. La segunda lectura, bien representada por Suárez-Galbán, sostiene que el eje de la angustia cadalsiana no es social, ni económica, ni profesional, sino psicológica, moral. Por tanto, la autobiografía tendría ante todo una dimensión confesional, de desahogo y análisis interior, o, haciendo una paráfrasis de la sentencia de Sánchez Espinosa copiada más arriba: la autobiografía de Cadalso es la crónica de una frustración personal que deviene al cabo en frustración profesional. Creo que el análisis que ofrezco en las siguientes páginas podrá demostrar la mayor validez de esta segunda lectura.

\section{EL ESTILO}

Suárez-Galbán ha calificado el estilo de Cadalso en su autobiografía como voluntariamente «casi anónimo» (art. cit., p. 116), en el sentido de que el escritor se oculta tras él con pudor, como si se resistiera a la autorrevelación. Pero asegura igualmente que es el mismo estilo de prosa que vemos en las Cartas marruecas. Si en lo primero convengo con su juicio, en lo segundo no estoy de acuerdo: Cadalso recurre aquí a una prosa poco literaria, en el sentido de que emplea escasos recursos retóricos y busca una narración llana, escueta e incisiva. Se delata una escritura rápida y me atrevería a decir que emocional: no está especialmente esmerada e incluso hay anacolutos e incorrecciones gramaticales, propias de una redacción carente de lima. Sin duda porque se concibió como algo que no iba a llegar hasta el público, está lejos de la prosa elegante y elaborada que emplea el gaditano en sus escritos mayores, como las Cartas marruecas. Su sintaxis rápida y nerviosa, de frase corta y a veces cortante, huye de matices y de circunloquios para expresar una verdad desnuda, en ocasiones demasiado desnuda como para revelar toda la complejidad emocional que contiene - de ahí tal vez esa sensación de reticencia y de misterio que queda en el lector-, casi como si sólo quisiera volcar en el texto la esencia de unos sentimientos que le dolería explayar en todos sus detalles y circunstancias.

A esto añade Cadalso un ingrediente más personal: el sarcasmo, que a veces roza la ironía autocompasiva. El uso del humor en esta autobiografía no ha dejado de ser advertido por los críticos, pero no siempre parecen darle el sentido que en realidad tiene. Suárez-Galbán, por ejemplo, lo contrapone al victimismo, como si Cadalso pasase de un cierto estilo ligero a 
otro más sombrío y desengañado ${ }^{20}$. En realidad, no hay nada contradictorio entre el recurso al humor y el tono de desengaño, ya que se trata de un humor autodestructivo: el desengaño va implícito en el propio humor, lo cual es precisamente lo nuevo ${ }^{21}$. Veáse por ejemplo la durísima presentación de Aranda, Cornel y Oquendo (cf. p. 100) u otro episodio desdichado que cuenta con ese mismo sarcasmo sombrío, su destierro de la Corte en 1768, que concluye humorísticamente: «Conjúranse contra mí varias ducas. Juno fue a Eolo, le mandó perseguir a los troyanos. Eolo, por complacerla, soltó los vientos contra Eneas, y yo, por orden de Villadarias, estimulado por la Benavente y otras, salí desterrado, empeñado, pobre y enfermizo, de Madrid, la noche última de octubre de 1768» (pp. 101-102). Ya en el destierro, sigue el chiste irreverente: cuando le pregunta alguien que ignora su desgracia qué hace en Zaragoza, contesta que «hice un voto a la Virgen del Pilar y lo vengo a cumplir» (p. 103).

Desde el punto de vista narrativo, Cadalso opera de manera muy selectiva, concentrando el interés de cada parte en episodios y ejemplos concretos y reduciendo al mínimo las transiciones, los fragmentos discursivos y las reflexiones de tipo general. Es, por tanto, una autobiografía de mínimos, en la que se desarrollan pocos asuntos, y aun ésos se desarrollan poco. Uno de esos pasajes bastará para evidenciar dicho apresuramiento: «Mesa, juegos, amores y alguna lectura ocuparon mi tiempo hasta que en 1764 levanté cincuenta caballos, por lo que me dieron la graduación en que me hallo hoy. Otras esperanzas pude haber fundado en dos lances al parecer más favorables» (p. 97). Tal jugosísima enumeración de asuntos suscita más expectativas que las informaciones que proporciona, pero el autor no considera preciso desarrollar ninguno de ellos. Este ejemplo da la medida de una de las consecuencias del estilo nervioso que he mencionado más arriba y de la rigurosa selección de la materia que acabo de señalar: la reticen-

${ }^{20}$ «Con ese su conocido estilo llano que Juan Marichal estudió de forma reveladora [...], comienza Cadalso contando los datos más relevantes de su vida de forma bastante escueta y lineal, aunque sin dejar de chispear a veces con humor. Ocurre, sin embargo, que, gradualmente, casi diríamos paulatinamente, se va imponiendo cierto tono de desengaño y desilusión que acabará por absorber todo», art. cit., p. 115.

${ }^{21}$ Esto lo han visto mejor Glendinning y Harrison, para quienes, pese al victimismo, Cadalso prefiere emplear la ironía para expresar su angustia. Es la principal diferencia con un texto como las Noches lúgubres, escritas en un tono quejumbroso: «La mayor parte del tiempo hace su crítica del mundo, de la suerte y de los valores de su época más bien con ironía y humor que con gestos trágicos. [...] la ironía de Cadalso es una manera de afirmar sus propios valores mediante la crítica o el rechazo de los de otras personas. Es también un modo de revelarse a sí mismo, criticando las cosas que no ha podido alcanzar», ed. cit., p. XIV. Redunda en esto Deacon: «Los sentimientos expresados en la Memoria nunca alcanzan, sin embargo, los extremos de las Noches lúgubres. La crítica del mundo está suavizada por el filtro de la ironía en lugar de manifestarse con todos sus colores, y de esta manera el autor se distancia del lector», art. cit., p. 328. 
cia, que parece dejar todo lo narrado en una nebulosa enigmática. Cadalso apunta muchas cosas que no cuenta pero parecen importantes: «proseguí mis diversiones, que me acarrearon una grave enfermedad en la Corte, de la que no me levanté sino después de mucho tiempo» (p. 98). ¿Qué diversiones? ¿Qué enfermedad? Esta velada confesión abre todas las conjeturas, hasta las menos favorables. También esto señala hacia el carácter privado, para uso personal, de esta obra.

Si la disposición de la materia tiende a lo episódico, hay que apreciar también que en esas minisecuencias narrativas en las que el contenido propende a agruparse, a menudo Cadalso hace gala de un registro narrativo vivaz y detallista, que no dudo en considerar como novelesco, como el embrión de un tipo de relato más circunstanciado ante el que, sin embargo, se detiene tras dar sólo unos pasos. Estos pequeños pasajes, incrustados en el hilo principal de la historia, que es mucho más panorámico, sorprenden creando altibajos en el estilo, pero también reflejan los valores de la memoria subjetiva, que obtiene la máxima expresividad de pequeños detalles que quedaron impresos en el recuerdo. Así cuenta el momento en que vio por primera vez a su padre:

Mi ayo y yo salimos al camino por donde había de llegar mi padre, a quien habíamos ya buscado una posada con mucha anticipación. A dos leguas hicimos alto esperándole [...]. Vi pasar un criado a caballo delante de una silla de posta de dos asientos. Sentí en mi corazón un golpe inesperado y prorrumpí diciendo: «Mr. Augé, en esa silla viene mi padre». Mr. Augé, que no creía en estos presentimientos, no hizo caso. Al mismo tiempo, mi padre, que efectivamente venía en la silla de posta con un amigo suyo [...], le dijo: «Molinillo, aquel muchacho es mi hijo». [...] La silla pasó. Llegó mi padre a la posada, y dos horas después llegamos a ella mi ayo y yo... (p. 90).

$\mathrm{Su}$ encuentro con Aranda en Zaragoza se introduce con este rápido bosquejo tan corto en tamaño como innecesariamente minucioso: «Fui temprano a casa del conde; llegué al cuarto de los capitanes. Oyó mi voz el conde y me envió a llamar. Entré...» (p. 104). Cualquier otro hubiera escrito simplemente que acudió a ver al conde: ése es, de hecho, el estilo que sigue Cadalso en el resto de la narración. Y lo mismo cabe afirmar de esta minisecuencia galante:

[...] llegué la noche del 10 de diciembre [...] al baile de máscara. La marquesa [de Escalona], enamorada todavía mentalmente de mí y corporalmente de don Antonio Cornel, me conoció, no obstante el disfraz; la hablé con la careta puesta; me dio un pañuelo que la pedí por quitarme el sudor; me habló y la dio una especie de congoja; la dije por qué aún no me había presentado. Pepe Olmuda, que estaba en todo el misterio, la dio un vaso de agua, y al volver del accidente la preguntó: «¿Es ese afecto de odio o de amor?» (pp. 105-106).

$\mathrm{Y}$ en otro momento emocionalmente intenso percute en el lector la 
manera en que persiguió al coche de Oquendo para reconciliarlo con Aranda y hacerlo volver a Madrid:

Llegué a Aranjuez al amanecer, porque la mula era perversa; fui al parador, y ya había marchado. Proseguí por el camino de Ocaña y vi de lejos el coche; lo alcancé y llegué a la puertecilla; le desperté, que iba medio dormido, y se sorprendió de verme en aquella hora y paraje (p. 107).

\section{LA SELECCIÓN DE LA MATERIA BIOGRÁFICA}

He señalado cómo el estilo narrativo de Cadalso se concentra en pocos asuntos. Conviene ahora ver cómo se realiza esa selección desde el punto de vista de la materia biográfica. Camarero resalta el principio inscrito en el título del opúsculo: «narra tan sólo los acontecimientos más particulares, y no toda su vida» (ed. cit., pp. 34-35). Es un hecho que no puede dejar de ser subrayado, pero que tiene otro importante matiz: esta severa selección sólo evoca situaciones fracasadas, esperanzas frustradas y personajes que le traicionaron. Así, da espacio a su padre ausente, pero no a los parientes que lo criaron y sí estuvieron presentes en su vida, a quienes ni siquiera cita por sus nombres ${ }^{22}$; de sus amores dedica unas líneas desdeñosas a la marquesa de Escalona, para mostrarnos su frivolidad, mientras que de María Ignacia Ibáñez hace una reticente mención remitiendo a otro texto que no se conoce hoy; de sus amigos sólo conocemos al marqués de Tabuérniga, y eso porque un día se emborracharon y se dieron de cuchilladas; y por supuesto, sí vemos a Oquendo y a Aranda, los traidores. No juzga oportuno decir nada de sus amigos literatos que hicieron más llevadera una vida aparentemente tan triste y que jugaron un papel crucial en la parte de Cadalso que más nos interesa, la literaria ${ }^{23}$.

Esta última exclusión sugiere a Deacon dudas «sobre la fiabilidad de las confesiones autobiográficas» (art. cit., p. 329). En realidad, pienso que eso no tiene que ver con la fiabilidad, sino con las prioridades del autobiógrafo: Cadalso selecciona el lado de su vida que le preocupa en 1773 y ese lado atañe a su despecho ante el fracaso que supuso su ruptura con

\footnotetext{
${ }^{22}$ «Los personajes principales de su infancia debieron ser su abuelo José Vázquez [muerto cuando el niño tenía cinco años] y la prima que cuidaba del gobierno de su casa, una jovencita llamada María Terrero y Vázquez, de unos trece o catorce años de edad» (GLENDINNING, ob. cit., 1962, p. 106), y luego se añade la influencia de su tío, el P. Mateo Vázquez. Cadalso se limita a hablar con vaguedad de una tía y de un tío jesuita.

${ }^{23}$ Deacon se sorprende de que el autor preste atención a personajes con quienes desea trabar amistad, «mientras que, por otra parte, algunas figuras consideradas por historiadores literarios como amigos íntimos suyos (Tomás de Iriarte, Nicolás Moratín, Meléndez Valdés y José Iglesias) ni siquiera son mencionadas, aunque sus estrechas relaciones con Cadalso quedan evidentes en la correspondencia», art. cit., p. 329.
} 
Aranda y Oquendo; en cambio, no considera que su vocación literaria sea materia de esta autobiografía. Por tanto, el gaditano no construye su identidad - al menos en el plano de su presentación pública- a partir de valores intelectuales o del deseo de pasar por sabio, por más que ya entonces fuese escritor eminente, lector infatigable y hombre de gran cultura y curiosidad ${ }^{24}$. Pero tampoco construye esa identidad a partir de su condición de militar, como cree Sánchez Espinosa, o de sus ambiciones cortesanas, ni escribe sus recuerdos seleccionándolos en clave aventurera o anecdótica al estilo picaresco, ni en clave histórica y testimonial, como testigo de su tiempo. Y, sin embargo, como veremos en breve, todas estas vías y algunas otras más se podrían haber planteado en una diferente selección de la materia biográfica.

En ese sentido creo que se puede hablar con propiedad de una autobiografía moderna, porque el autor se retrata como un individuo cuya identidad no depende de su oficio, de su cultura ni de ningún elemento particular de su vida externa. Por ello, estoy en desacuerdo con Sánchez Espinosa, que asegura que la obra cadalsiana tiene como objeto la carrera civil, para luego afirmar que se articula en etapas tales como origen familiar, educación, toma de estado... A mi juicio lo significativo no es la clase de asuntos que se cuentan, sino desde qué punto de vista y con qué intención. ¿Es que acaso no hay relación entre todas esas cosas, y aun entre el propio concepto de carrera civil y la conciencia del individuo, supuesto objeto de una autobiografía moderna? En la vida y en el alma de una persona no se pueden separar la faceta pública y la íntima como si la primera fuera sólo un traje que viste a la segunda. La vida profesional puede enfocarse desde el punto de vista interior, que es lo que hace Cadalso, igual que una crónica de la vida estrictamente privada puede no decirnos nada de la personalidad de quien la vive. Debemos preguntarnos más bien desde qué perspectiva ilumina Cadalso los hechos de su carrera, y esa perspectiva es emocional, tiene que ver con el estado de su alma y con el concepto moral que posee de sí mismo. El propio Sánchez Espinosa introduce algunas restricciones en su consideración del texto como memorias:

[...] hay elementos en las memorias de Cadalso que parecen acercar el texto a la autobiografía. Nos referimos a algunos desarrollos de sus relaciones amorosas y de amistad que, en cierto modo, pugnan por escapar la esfera del hom-

${ }^{24}$ De sus estudios dice poquísimo. Como un rasgo más de su carácter, se acuerda de especificar que en Lyon y en París «me ocupé [...] en comprar los mejores libros que pude, y lo mismo ejecuté en Londres» (p. 95). En esta última capital, «la reclusión que yo mismo me impuse, la lectura a que me obligué y el mucho tiempo que gastaba solo en mi cuarto, me pegaron este genio que he tenido después, y el amor a los libros» (p. 95). Aquí acaban las referencias a su condición de escritor, salvo algunas frases dedicadas a las Cartas marruecas y a ciertos textos que presentó a Aranda para ganar su favor, siempre evocados en función de otros fines y no en relación a la literatura misma. 
bre social para revelar aspectos del hombre privado. [...] Creemos, sin embargo, que esta posible consideración es sólo un efecto de una interpretación «romántica» o «prerromántica» de Cadalso por parte del lector, que interpreta como pertenecientes al hombre privado aspectos que el tiempo y mentalidad del autor adscribe sin problemas al hombre público (ob. cit., p. 185 ${ }^{25}$.

De este modo relega a la marginalidad, como algo secundario, eso que llama «algunos desarrollos de sus relaciones amorosas y de amistad» y que en realidad ocupan un lugar centralísimo de la obra. Pero, además, el principio que formula a continuación es todavía más erróneo. ¿En qué sentido se considera en el XVIII que las relaciones amorosas y de amistad pertenezcan a la esfera pública? Más bien ocurre al contrario, el pudor hacia lo sentimental excluye esa materia de la representación autobiográfica, y la recluye, si acaso, en el sentimentalismo menos comprometido de la poesía. No hay anacronismo en interpretar dentro del ámbito privado pasajes como los que Cadalso dedica a su amistad con Oquendo y la prueba es que resulta muy difícil hallar algo parecido en cualquier otro autobiógrafo español de la época: es algo que autores y lectores perciben netamente separado de la esfera del hombre público ${ }^{26}$. Cadalso ha dado cabida en su relato autobiográfico a aspectos íntimos y privados, algunos de ellos tan impúdicos e inaceptables para la buena sociedad madrileña en la que se movía el escritor como el sarcástico retrato de su padre, las breves referencias despectivas a sus amoríos con una marquesa y las breves referencias afectuosas a sus amores con una cómica. Por ello, es más relevante el hecho de que aparezcan esos retazos de intimidad que el hecho de que lo hagan de modo tan cauteloso.

En señalar esa cautela se ponen de acuerdo las antagónicas lecturas de Embeita y Sánchez Espinosa, ya que también la primera había reparado, pese a creer que se trata de una autobiografía rousseauniana, en lo poco que se ocupa de su padre, de su infancia, de su adolescencia y sus amo-

\footnotetext{
${ }^{25}$ Sánchez Espinosa parece seguir aquí a Glendinning y Harrison, que matizan su dictamen sobre el carácter más social que íntimo del texto con este balance: «Quizá Cadalso hubiera cambiado un poco el equilibrio de sus Memorias si hubiera escrito las notas que prometía sobre María Ignacia Ibáñez, sobre Vallés, y sobre otros contactos con personas de una esfera más humilde. Y es de lamentar, desde luego, que Cadalso no haya concluido esta obra. Se le quedaron en el tintero bastantes cosas, o también es posible que se haya perdido lo que redactaba como materia adjunta a la narración principal. No obstante, la Memoria y sus continuaciones revelan la facilidad que su autor tenía para contar; su creencia en el proceso de causas y efectos; su perspectiva irónica sobre la vida, la fortuna y la sociedad; su deseo de aprecio y su necesidad de amistad. Revelan también algunos de los problemas sociales de su tiempo y su mezcla de egoísmo y desinterés nos da lo que siempre interesa en la literatura, el retrato de un hombre que tiene problemas y que hace lo que puede para resolverlos, un ser humano», ed. cit., p. XV.

${ }_{26}$ Véase sobre esto el capítulo XIV de mi citada tesis doctoral.
} 
res, al contrario que hace Rousseau ${ }^{27}$. Es una observación acertada, pero que sólo tiene sentido en el contexto de un ejemplo como el del ginebrino o el de tradiciones autobiográficas que no sean la española. Si no queremos descontextualizar a Cadalso, hay que hacer hincapié en el hecho de que, por poco explícito que sea en las materias íntimas y privadas, ya va más lejos que sus contemporáneos españoles y que muchos de los que le siguieron por este camino décadas después.

Dicho esto, ya es hora de enfrentarse a la manera en que se desmenuza en el texto esta corta y peculiar selección de la materia biográfica. La Memoria de los acontecimientos más particulares de mi vida aparece dividida en varios epígrafes temáticos, que voy a agrupar para su estudio en cuatro bloques: 1. Relato genealógico, que abarcaría los epígrafes «De mi familia», «De mi abuelo» y «De mi padre» (pp. 87-89). 2. Infancia, educación y toma de estado, con los epígrafes «De mi nacimiento», «Morada en el Colegio de París», «Llegada de mi padre a París», «Primera morada en Inglaterra», «Vuelta a París» y «Vuelta a Madrid» (pp. 89-96). 3. Carrera militar y relación con el Conde de Aranda: «Campaña de Portugal», «Intervalo de tiempo hasta la guarnición de Madrid», «Salida o destierro de Madrid, ida a Aragón, encuentro con el conde de Aranda» y «Regreso a Madrid. Aventuras de todas especies hasta mi salida voluntaria para el regimiento en el día 8 de mayo de 1773 a Salamanca» (pp. 96-112). 4. Adiciones posteriores (pp. 113-123).

Los dos primeros bloques configuran un mismo núcleo de interés: aunque son los habituales preliminares biográficos de toda autobiografía, giran en torno a un asunto privado, la relación con su padre, y a un asunto de su vida pública, la elección de carrera, si es que en esto último se puede diferenciar lo privado de lo público. El tercer bloque muestra sus intentos de progresar en la carrera elegida, lo que constituye el cuerpo central de la autobiografía, aunque el relato acaba siendo atraído hacia un punto que se configura como su eje psicológico, la relación con Aranda y su círculo.

\section{ABUELOS, PADRES Y DESARRAIGOS: RELATO GENEALÓGICO Y DE INFANCIA}

Comenzaré comentando el relato genealógico de la autobiografía del escritor gaditano. ¿Gaditano? Esto no parece tan claro. Suárez-Galbán afirma que uno de los móviles psicológicos que explican la obra es el senti-

\footnotetext{
27 «Resuelve los problemas que entraña la acumulación de detalles y recuerdos y la consiguiente selección con excesiva simplificación, hasta el punto que no puede evitarse la pregunta fundamental al analizar la obra, las omisiones. [...] Cadalso apenas roza la adolescencia, y sólo nombra la infancia, épocas las más interesantes para la génesis de la personalidad...», EMBEITA, art. cit., p. 323. De igual modo, afirma más adelante que «los amores no ocupan mucho lugar», ibíd., p. 324.
} 
miento de desarraigo, propio de alguien que se crió sin familia directa (madre muerta, padre ausente, sin hermanos) y al que enviaron muy niño a educarse en el extranjero. Una forma de compensar esa falta de raíces es, según el crítico, enorgullecerse de sus orígenes vascos: «...con escasa razón objetiva para ello, Cadalso dice sentirse vasco, y [...] su Memoria comienza justamente señalando este origen [...]. No dice, en cambio, el lugar de su nacimiento, y salta por encima de los primeros años de infancia - tema de tantísima importancia tanto para la sicología como para el género autobiográfico - para pasar a hablar en seguida de su llegada a París...» (art. cit., p. 119) ${ }^{28}$. Por mi parte, no creo que en el texto se exprese un orgullo de ser vasco ni haya una complacencia en desenterrar su árbol genealógico, sino más bien lo contrario. Copiaré los dos primeros epígrafes:

De mi familia. Dicen que mi casa solar está en un lugar pequeño de Vizcaya, llamado Zamudio. Aseguran que es muy antiguo. Añaden que en los ayuntamientos del pueblo [...] las hembras de mi familia tienen voz, como los varones de otras. Consta también que tiene un escudo de armas nada vulgar. Buenas casas todas. Se me abre la boca de par en par [para bostezar] cuando hablo de ellas, porque así como a otros es un especialísimo incentivo la conversación de genealogías, he experimentado que es para mis humores el mejor soporífero que puede inventarse. Habiendo leído menos de autores de blasón que de poesía y filosofía, no puedo desechar de mí aquello de Horacio: Nam genus et proavos, et quae non fecimus ipsi, / vix ea nostro voco... ${ }^{29}$

De mi abuelo. Fue un hombre que se fue al otro mundo sin vestirse a la castellana ni hablar castellano; muy llena la cabeza de que un antepasado suyo había sido algo con Carlos V, no le pareció justo trabajar en ser algo con Carlos II ni Felipe V. Pero para que se vea cuán a paso de gigante camina el hijo, mi abuela encargó que le enviasen de Bilbao un hombre que le enseñara el español a sus muchos hijos, pues entre los de su matrimonio y los de las primeras nupcias, me dio mi abuelo un padre y veinte tíos y tías, de los cuales la mayor parte han muerto, quedando sólo dos, uno muy rico y feliz, y otro muy triste y pobre (pp. 87-88).

Cadalso se distancia de cualquier pretensión de fundar su autoestima o la estimación ajena en su linaje de hidalgos vascongados. Su actitud es individualista, es decir, burguesa. Al evocar su solar y su familia lo hace de forma humorística como motivo de bostezos, y destaca el atraso y la ignorancia rural en que vivía su abuelo más que cualquier otra cualidad: lo ridiculiza porque no hablaba castellano y lo contrapone a su padre, quien «nació con demasiada viveza para gastar su vida en hablar vascuence, beber

\footnotetext{
${ }^{28}$ Suárez-Galbán desarrolla más su argumentación, pero los textos más claros que cita pertenecen al epistolario, no a la autobiografía.

29 En realidad, la cita procede de las Metamorfosis de Ovidio: «Creo que no deben considerarse nuestros ni el linaje ni las hazañas de los antepasados» (de la nota de Camarero, ed. cit., p. 88).
} 
chacolí, plantar castaños y conversar de abuelos...», despectivo resumen de la vida vasca de sus antepasados.

Pero además de expresar esa distancia hacia sus ancestros en términos racionales (¿cómo podría estar orgulloso de esos pueblerinos incultos?, parece sugerirnos), lo hace también en términos personales, al colocar estas noticias en una vaga tercera persona del plural que aleja de sí la responsabilidad de esas afirmaciones: «dicen que mi casa solar está...», «aseguran que es muy antiguo», «añaden que...», «consta también...», como si con él no fuera nada de este asunto, donde otros citarían registros y documentos que demuestren su alcurnia. También se distancia en términos ideológicos, al rebuscar en su memoria una cita latina que rechaza expresamente la nobleza hereditaria y al afirmar por su cuenta que su abuelo no hizo nada por sus reyes porque ya lo habían hecho sus antepasados por Carlos V: esa guasa remite a la reprobación ilustrada de la nobleza ociosa, que tan bien se ejemplifica en algunas de las Cartas marruecas. Se trata, en suma, de despreciar la mentalidad aristocrática: aunque podía presumir de hidalguía, pesa más en él la actitud burguesa de su padre, dinámico comerciante afincado en una ciudad mercantil como Cádiz ${ }^{30}$.

El segundo bloque que he señalado se ocupa de la infancia, la educación y de la elección de carrera. En toda esta sección es llamativa una cosa: apenas da datos sobre su crianza, sino que el texto gira precisamente en torno a aquello que estuvo más ausente: su padre. No le interesan sus estudios, ni su curriculum académico, ni su formación, apartándose en esto, con claridad, del formato propio de una vida literaria. Durante este periodo de su vida Cadalso se mueve por decisiones de unos parientes que no nos dice quiénes son. No habla de su madre, ni indica el lugar donde él nació; sólo menciona por su parentesco, no por sus nombres, a las perso-

\footnotetext{
${ }^{30}$ Camarero, al contrario que Suárez-Galbán, aprecia el distanciamiento de Cadalso respecto a sus orígenes, pero no lo cree sincero: coloca una nota en este pasaje de la autobiografía relativizando la actitud displicente del autor. Por un lado, cita una opinión de Glendinning acerca de que Cadalso «no deja de sacar a relucir el rancio abolengo de su casa» y, por otro, añade que «luego bien se preocupó de procurarse el hábito de Santiago; parece que hasta pensó entablar la pretensión de una encomienda en 1777» (ed. cit., p. 87). Ninguna de las dos afirmaciones contradice la actitud antinobiliaria del autor: la segunda es trivial, ya que a lo que no renuncia Cadalso es a su aspiración de medro social, y para ello recurre, como es lógico, a todos los méritos que pueda aducir para obtener beneficios en una sociedad que valora mucho - demasiado, según el propio Cadalso - el linaje aristocrático. Respecto a la primera afirmación, incumbe a la propia naturaleza referencial de una autobiografía: Cadalso menciona su abolengo, pero es que de hecho él posee dicho abolengo, forma parte de su vida y es lógico que lo mencione. Desde luego que pudo haberlo no hecho, pero es obvio que cualquier dato objetivo de su vida es susceptible de ser presentado y no es su aparición, sino su tratamiento, lo que hay que interpretar. Más aún, es significativo que lo saque a colación, porque eso lo coloca en la línea de la autobiografía moderna, en la que la evocación de los orígenes es un punto clave.
} 
nas que le criaron desde niño. Todo incide en el desarraigo: abandonado en un mundo apenas descrito, del que sólo se escoge un puñado de sucesos y personas, siempre negativos, siempre decepcionantes, empezando por el padre. De su progenitor lo que evoca es, por cierto, su ruptura con el solar vasco: podemos entender entonces que su propio desprecio del linaje ni siquiera lo efectuó él, sino que lo heredó de su padre.

Su padre domina el recuerdo de Cadalso precisamente por su alejamiento físico y afectivo. Ahí se revela una quiebra en su personalidad: la figura paterna confiere una hondura psicológica a esta autobiografía difícil de apreciar en otras obras españolas (hay trazos en las memorias de Juan Antonio Posse y José María Blanco White, y una versión harto más desquiciada en la Vida trágica de Santiago González Mateo ${ }^{31}$; por lo demás tendríamos que esperar hasta Zorrilla un siglo después para ver algo semejante). Aunque se trata de pasajes breves - como todos los de este apresurado opúsculo-, no por ello son menos importantes. Cadalso no somete esta relación a un desarrollo analítico, pero todo lo que atañe a su padre rezuma sarcasmo e incluso hostilidad: tal vez no se atreve a desentrañar sus sentimientos, pero los va diseminando con comentarios envenenados que, juntos, dibujan un retrato amargo. Véase a este respecto la intensidad y detalle con que está narrado su primer encuentro con el padre, que de hecho es el único suceso concreto que evoca de su infancia (cf. p. 90, lo he transcrito más arriba).

El padre es pintado como de fuerte carácter, antojadizo, voluntarioso, imperativo; se nota que Cadalso lo ha analizado a fondo y ha sacado conclusiones no muy favorecedoras: «me avisó que iba a París, para tener el gusto de dar un abrazo a su unigénito hijo», «es de notar que iba yo a cumplir trece años, sin conocer a mi padre», «me dio un beso en la frente; casi, casi nos enternecimos», «de allí a poco [ocho días después de ver a su hijo por primera vez] se le antojó aprender inglés y [...] se fue a Inglaterra», «las órdenes de mi padre no eran capaces de interpretación» (pp. 9091, cursivas mías). Dice que las costumbres inglesas eran «muy análogas al carácter de mi padre» (p. 91), para más adelante caracterizar sobre sí mismo ese estilo vital inglés con el concepto de «aspereza». Luego habla de «la natural sequedad de su genio», refiriéndose también a su padre, quien «sin haber estudiado matemáticas tenía el espíritu más geométrico del mundo, no sabía qué hacer con un hijo tan irregular», y menciona «su formalidad acostumbrada», que era un «hombre [...] metido en sí», que «jamás me habló de tú» y que le amenazó con que si le hablaba «a la

${ }^{31}$ Véase F. DURÁN LÓPEZ, «Padres e hijos: el relato genealógico en la autobiografía de Santiago González Mateo», en Alberto Ramos Santana (ed.), La identidad masculina en los siglos XVIII y XIX. De la Ilustración al Romanticismo (1750-1850). VIII Encuentro. Cádiz, 17, 18 y 19 de Mayo de 1995, Cádiz, Universidad, 1997, pp. 69-84. 
tercera vez» de su deseo de ser militar, «no tiene padre» (pp. 93-94). En última instancia, lo retrata como colérico y un tanto desaforado: la primera vez que le sugirió que iba a ser jesuita, estas insinuaciones «le volvieron loco» (p. 93) y cuando murió en viaje por Dinamarca, lo hizo «mal satisfecho del señor Esquilache y delirando en materias de Estado» (p. 95, cursiva mía).

En el primer bloque, referido a su infancia, la imagen paterna se evoca sobre todo por su impronta en una personalidad - la suya - no formada, y por lo tanto no descrita. En cambio, en un segundo momento, lo que se plantea es un conflicto entre dos personalidades ya puestas a un mismo nivel: Cadalso y su distante padre. El motivo del conflicto es el futuro oficio del hijo, que quiere ser militar y, para sortear la oposición paterna, lo trata de convencer para ser jesuita, consciente del antijesuitismo de su progenitor. En esta lucha se deja vẹr en Cadalso una rebeldía que se corresponde de forma natural con el rencor hacia el padre. Se declara libre de costumbres por su educación europea y su padre - para compensarlo- lo hace entrar en el Seminario de Nobles; el choque es inevitable: «Desde el mismo día empecé a tratar el modo de salir de aquella casa, que no se me podía figurar sino como cárcel. Pero mi padre era hombre tan metido en sí, que me era poco menos que imposible saber qué medio sería el más eficaz para este fin. Por fin pude adivinar que me quería para covachuelista, cosa que se oponía a mi ánimo, que era militar» (pp. 92-93). La resolución del asunto, total triunfo del arbitrario padre y sumisa obediencia del hijo, pone de manifiesto la repercusión de esta crisis en su carácter:

\begin{abstract}
El año y medio que duró esta ficción [su estancia en Londres por orden paterna], la reclusión que yo mismo me impuse, la lectura a que me obligué y el mucho tiempo que gastaba solo en mi cuarto, me pegaron este genio que he tenido siempre después, y el amor a los libros. Como aún era yo muy joven y en la edad precisa de tomar incremento las pasiones, contribuyeron estas circunstancias a apagármelas más de lo acostumbrado (p. 95).
\end{abstract}

Cadalso sólo se liberó con la muerte de su padre, que evoca sin pena ninguna, sino más bien con sorna. Esto supuso su entrada en el ejército y la ruina de su patrimonio, rompiendo así su último lazo con la familia y con la sombra paterna, pero también conduciéndole a la precaria situación económica que va a arrastrar el resto de su vida. Así lo percibe al proyectar la mirada hacia atrás: «Este golpe de heredero francés fue la piedra fundamental de la ruina de mi patrimonio [...] yo nunca supe la verdadera suma de mi patrimonio, ni vi jamás el testamento de mi padre, ni supe qué tenía hasta que supe que ya no tenía nada» (p. 96) ${ }^{32}$.

\footnotetext{
${ }^{32}$ No todos conceden la misma importancia a la relación de Cadalso con su padre. Me sorprende en especial la lectura de Embeita, quien cree que esta autobiografía «define a su sujeto, Cadalso, enmarcado en sus orígenes, no en oposición a ellos» (art. cit.,
} 
Así pues, Cadalso detalla estos episodios por la importancia que psicológicamente ha concedido a la confrontación con el padre y a través de ella a la definición de su propio carácter, pero también porque se trata de los preliminares de su elección de carrera, que es el nudo de la frustración y el miedo que le atenazan en el momento de ponerse a escribirla.

\section{EN EL CÍRCULO DE ARANDA}

La larga sección que he designado como tercer bloque, verdadera nuez de esta autobiografía, se consagra a los vaivenes de su relación con el conde de Aranda y, secundariamente, a hechos militares sueltos, anteriores a esta amistad, así como a amargos lances amorosos y quejas sobre su pobreza. Algunos temas literarios ocupan un papel muy marginal en función de los intentos de Cadalso de hacer carrera política.

La muerte del padre le deja en libertad de entrar en el ejército. La primera cosa que hizo al sentar plaza fue acudir al campo de batalla contra Portugal: «fui testigo de aquella guerra con harto dolor de mi corazón» (p. 96). Testigo, dice, y no protagonista, porque no nos cuenta que haya combatido, de forma que, si lo hizo, no le interesó presumir de ello. Pero ni como testigo ni como protagonista tiene el menor deseo de introducirse en una narración bélica o en la descripción del ambiente militar. En contra de lo que afirma Sánchez Espinosa, no hay nada que rememore la camaradería y la vida militar. El único suceso que impresiona su memoria de esta campaña -es lo que parece justificar ese ponderado dolor de su corazónes una trifulca de borrachos con su condiscípulo, el joven marqués de Tabuérniga.

[...] habiendo bebido a la alemana a la comida, saliendo a la noche de nuestra tertulia le dije no sé qué palabra que le ofendió, sacó la espada de repente y me pasó un botón de la casaca de la primera estocada, antes que yo hubiese reparado que tal espada tenía. En esto saqué la mía, que era de a caballo, pesadísima para manejar a pie, pero tuve la fortuna de abrirle la cabeza, la mano y el puño de su espadín, todo de una cuchillada, con lo que pude recogerle y llevarle a casa. De allí a poco se serenó. Cenamos; habló divinamente sobre varias cuestiones que se suscitaron, algunas muy profundas, se acostó y se durmió (p. 96).

Este episodio posee un valor anecdótico y eso es lo único que explica su inserción: Cadalso tantea una posible línea narrativa, como hace otras veces, pero no se decide a seguirla. Éste y algunos pasajes más, como el

p. 323), y que expresa un «enfrentamiento oblicuo con el padre» (ibíd., p. 323). No sé en qué sentido puede entenderse como oblicuo un choque de caracteres y de intereses tan frontal como el narrado en las Apuntaciones autobiográficas. 
incidente con los espías de Aranda, han hecho a algunos evocar el influjo de las vidas de soldados del XVII y las novelas picarescas. En apariencia, se asemeja a los lances violentos que jalonan esas narraciones reales $o$ ficticias, pero la semejanza no ha de ser magnificada: se trata de piezas integradas en un engranaje literario muy diferente.

Me interesa más recalcar cómo esta anécdota, sumada a otros de los asuntos contenidos en la autobiografía, demuestra que Cadalso no desea fabricar una imagen dulcificada de sí mismo: no le importa dar cabida a hechos infamantes. Eso prueba que no estaba pensando en un público al que impresionar, porque nada de lo que ha contado hasta este momento, y menos aún esta reyerta en que da una estocada a un marqués, podría interesar objetivamente o predisponer en su favor a unos hipotéticos lectores. Cadalso selecciona sus recuerdos más intensos, aunque no sean coherentes entre sí: la frialdad terrible 'de su padre, esta pelea, algunos posteriores amoríos, la traición de Oquendo... Nada de ello apunta a una imagen pública digna, sino a un desahogo de su subjetividad.

Los siguientes trozos de la autobiografía alternan diferentes tentativas de colocarse en la corte en un buen lugar. Anuncia que va a relatar dos lances en que tuvo ocasión de medrar, para explicar cómo su probidad quedó demostrada en ellos, incidiendo por tanto en el hecho de que, pese a su contrastada hombría de bien, la virtud no recibe recompensa. El primero de ellos es enigmático: se le encomendó un informe sobre una cuestión que tocaba a la Compañía de Jesús y que iba a leer el propio rey.

Entonces pude haber hecho gran negocio con los jesuitas, informando a su favor, o con el ministerio, informando contra la Compañía [...]. Ésta fue la primera experiencia que hice de mi hombría de bien, y fue preludio de algunas otras. Me separé de ambos respetos e informé como hombre de bien la verdad lisa y llana (p. 97).

Si en su altercado con Tabuérniga Cadalso no quiso seguir el camino de una autobiografía anecdótica y apicarada, ahora se le abre otra vía: el testimonio histórico. Tampoco elige esa opción. Lo interesante desde un punto de vista objetivo hubiera sido aclarar en qué consistía ese misterioso asunto, que tal vez arrojaría luz sobre el proceso que condujo a la expulsión de los jesuitas. Al escritor le trae al fresco ofrecer ese documento para la historia e incluso el asunto en sí, lo que le interesa es dar la medida de su recto proceder, es decir, caracterizar su dimensión moral de hombre de bien: el valor que el episodio posee es puramente subjetivo.

El segundo suceso es de naturaleza intelectual. Un preceptor jesuita de la familia real le encarga una traducción del inglés de un libro sobre astronomía. «Lo hice y bien y en pocas horas» (p. 98). Pero tras la expul- 
sión de los jesuitas, Cadalso perdió esa posible recomendación dentro del círculo más influyente de la corte. Ocurre igual que antes: se abre otro posible desarrollo autobiográfico, en este caso desde el punto de vista de la labor intelectual, pero Cadalso prefiere ceñir el asunto a sus expectativas personales en la corte.

Del motín de Esquilache se limita a contar que durante su transcurso salvó la vida de Alejandro O'Reilly de las iras del populacho: «O'Reilly no lo ha sabido, ni yo lo diré» (p. 98). Otra vez se trata de acreditar sus méritos personales, no de contar el episodio ni de ofrecer un testimonio histórico. Después del motín se produce el ascenso político de Aranda, para quien Cadalso tiene durísimas palabras; aunque se disfrazan de un comentario sobre la coyuntura política, en realidad el autor vuelca el fruto de su experiencia traumática con el conde años después, no sus opiniones de 1766: «el conde de Aranda [...] en vez de aquella sobrada intrepidez que se le notaba, iba a abatir su espíritu, humillar su genio y envilecer sus empleos, cobrando miedo a todas sus hechuras» (p. 99).

El vaivén temático a que le van arrastrando su memoria y el vago hilo cronológico seguido le lleva también a introducir en el espacio literario su vida amorosa, otra de las señas que distinguen a la autobiografía moderna. Este pasaje no tiene desperdicio, ante Cadalso el relato abre una nueva senda, su itinerario galante:

Enamoréme allí [en Alcalá] sucesivamente de la hija de un consejero llamado
Codallos y de la marquesa de Escalona. El fin del primer amor fue el princi-
pio del segundo, y éste se acabó luego que vi que en la marquesa no había
cosa que dominase mi espíritu ni complaciese mucho mi carne. No obstante,
seguí esta amistad todo el tiempo que estuve en Madrid. Con la de Codallos
pudo haber sido la cosa muy seria, porque siendo ella soltera y yo también, y
mezclándose en eso tres sujetos muy intrigantes, estuve muy cerca de casarme
con ella, y aun lo hubiera hecho, a no considerar que me quedaban ya muy
cortas reliquias de mi patrimonio y tener el corazón demasiado humano para
ponerme a hacer chiquillos, que con el tiempo pedirían limosna. Lo que hicie-
ron por casarme y lo que hice para que no me casaran, merecen una historia
aparte (pp. 99-100).

No es una historia romántica. Ya es mucho que Cadalso considere adecuado contar sus amoríos en términos tan directos como para decir si una marquesa complacía o no su carne, pero lo más aleccionador es que el tema amoroso - como los demás que van surgiendo - se reconduce al problema de su acomodo social y la restauración de su patrimonio, que guardan tanta relación con su propia identidad. Y, por supuesto, está el asunto de la hombría de bien, que en este caso se expresa por su repugnancia a formar familia sin tener asegurado su sustento. La reticencia final evoca otra posible autobiografía, que no constará en estas páginas, porque el motivo 
de traer a colación estos amores, su imposibilidad económica de casarse, ya está cumplido ${ }^{33}$.

A partir de este punto, el relato está dominado por su trato con Aranda. Conoce al conde y trata de congraciarse con él por medio de uno de sus escritos, carta de presentación ante el político: «le llevé un manuscrito en que me había yo forjado un sistema de gobierno a mi modo, bajo el estilo de una novela y el nombre de Observaciones de un oficial holandés en el nuevamente descubierto Reino de Felitzá» (p. 100). Hasta entonces ni siquiera había salido a relucir que fuera escritor. Al presentar el encuentro y a los nuevos amigos que se derivan de él, Cadalso trasluce su rencor, a la luz del desastre a que le ha conducido este círculo de amistades, con una oscura ironía:

[...] me dijo haberlo leído y haberle gustado; pero como señores de tan altas ocupaciones suelen mentir con tanta frecuencia como benignidad, no tomé la cosa muy al pie de la letra, hasta que me la persuadieron sus favoritos, don Antonio Cornel y don Joaquín Oquendo, que habían sido sus pajes, y a quienes hizo más rápida fortuna que la que el rey suele hacer a los suyos. Fueron tantas las fiestas y agasajos que me hicieron estos dos jóvenes, que empecé a tratarles con intimidad, tanto por respeto a su amo como porque ellos por sí mismos tuvieron atractivo con las gentes, mientras no conoció éste la vanidad y no tuvo el otro cuarenta mil pesos ganados en la banca (p. 100).

Tras este primer contacto, viene su destierro a Zaragoza en 1768, que relata con el mismo amargo humor, pero repitiendo fúnebremente que estuvo en la capital del Ebro «desterrado, empeñado, pobre y enfermizo» (p. 102) y «enfermo, pobre, empeñado, desterrado y desconocido de toda aquella nobleza» (p. 103). Cuenta con el consuelo de algunos amigos, del trato social que poco a poco se le abre y de su labor como poeta, inaugurada por entonces con sus Ocios de mi juventud: de nuevo sale a colación su trabajo literario sólo para ilustrar su estado anímico.

En Zaragoza afianza los lazos con Aranda. Vuelve por fin a Madrid y, según nos cuenta con mucho misterio, desata sus últimas ataduras amorosas con la marquesa de Escalona: «Desembarazado totalmente de amor, me dediqué únicamente a cultivar la amistad de Oquendo, en quien hallé cada día más fineza» (p. 106). La relación entre Aranda, Oquendo y Cadalso configura un triángulo emocional de tintes que algún crítico más dado a

\footnotetext{
${ }^{33}$ Había mencionado el tema amoroso antes, concibiéndolo como una pasión adolescente perjudicial: «Allí [en Inglaterra] experimenté por primera vez los efectos de la pasión que se llama amor. Hubo de serme funesta» (p. 91), para luego advertir que su segunda estancia en Inglaterra, tan ascética y recogida, apagó estas pasiones. Hay otros dos pasajes de contenido amoroso después: la escena que ya he citado del baile que da la marquesa de Escalona, su antigua enamorada (pp. 105-106); y la presentación muy sentida, pero reticente, de María Ignacia Ibáñez, que copio más adelante.
} 
especulaciones sin duda acabaría por calificar como homosexuales ${ }^{34}$. El trato entre los tres fue borrascoso y Cadalso narra sus altibajos con intensidad, cuidándose de especificar, despechado, los agravios que Oquendo le va haciendo. En el momento en que escribe estas páginas sigue siendo el asunto que más le compromete emocionalmente, sólo se le acercan de lejos los problemas con su padre, pero éstos son lejanos, mientras que el dolor por su amistad traicionada aún le quema.

La relación entre el conde y su protegido Oquendo es frágil - discusiones como de padre e hijo, llega a decir Cadalso, con su mala opinión de los lazos paternofiliales-: rupturas, celos, reconciliaciones, exigencia de Aranda de que Oquendo terminase su relación con cierta mujer, abuso de confianza por parte del más joven... Cadalso actúa como intermediario, arreglando sus problemas sin que Oquendo se lo agradezca, aunque sí Aranda, de quien cuenta que le dijo: «Cadalso, Vm. es hombre de bien y buen amigo» (p. 107). Pero Oquendo estaba celoso de la simpatía que Cadalso despertaba en Aranda, pues temía llegase a suplantar la suya propia. «Desde este instante se me fue preparando la caída tan completa, porque aunque al punto pareció y debió haberse estrechado más nuestra amistad, conocí que era el final de ella» (p. 108).

Oquendo volvió a enfadar a Aranda al reanudar las visitas a su amante y suplicó a Cadalso que lo ayudara. En otro episodio picaresco, el gaditano lleva una carta a la incómoda y anónima dama, pero es seguido por los espías del conde y se ve obligado a apalearlos. Así cayó en desgracia ante Aranda. Éste es el meollo del texto de 1773, el momento en que Cadalso hace gala de la nobleza de su corazón y de la hombría de bien que considera su mejor cualidad: antepone su amistad con Oquendo a su beneficio propio. En la frase más significativa del relato, le dice a éste antes de cumplir su encargo: «Amigo, voy a perderme también como Vm. se ha perdido. Primero es mi amigo que mi fortuna. No perdamos tiempo; hasta mañana» (p. 108). Así pues, tantas vueltas con su ambición y su deseo de medro, pero en realidad lo echa todo a perder por un gesto de generosidad que no le ha sido agradecido. ¿Qué le duele más, haber caído en desgracia

\footnotetext{
${ }^{34}$ Embeita afirma que «ya ha señalado acertadamente la crítica [se refiere a Sebold] que más que amistad, esta devoción solícita era una forma de amor platónico, cuya inspiración se halla en Rousseau, de tan clara influencia en Cadalso» (art. cit., p. 324). En el pasaje arriba copiado se muestra su amistad con Oquendo como heredera emocional de sus amores malogrados con la marquesa. Igualmente, la sitúa en un determinado momento en contraposición a las relaciones amorosas: «No se hallaba sin mí: todo me lo preguntaba, todo me lo confiaba, todo me lo consultaba; hízome una de aquellas declaraciones que entre los amigos verdaderos son más tiernas y más sólidas y de más noble objeto que las que se hacen los amantes. En fin, nos prometimos una amistad eterna, que yo no he quebrantado sino a su ejemplo y en mi daño» (pp. 104-105). Es evidente que Cadalso concede a la amistad un lugar altísimo en la jerarquía de sus valores y de sus pasiones, que no cede en absoluto ante el amor erótico.
} 
o la traición del amigo? ¿Su carrera pública o la pérdida íntima? Tal y como lo cuenta, es esto último lo que le atormenta. Además, quiere ver aquí una constante de su destino, el eje de su imagen personal en esta autobiografía: antepone su hombría de bien a su interés, pero la virtud es castigada $^{35}$. La ambición queda en segundo plano.

Desde este punto se conjura toda la casa contra mí. El conde, por lo dicho y tal vez algún influjo más; Oquendo, porque no creyó que hombre alguno de este mundo despreciaría su amistad; el criado dicho, por acabar de dominar a Oquendo, que dominaba al conde, y los demás, por ir con la corriente (p. 109).

En esta caída aparecen sus amores con María Ignacia Ibáñez, que sin embargo remite a un escrito separado. De su breve comentario se desprende una gran pasión, pero otra vez inserta en el marco de su conflicto con Oquendo:

Tal vez me hubiera tentado mi desgracia a dar este paso tan ajeno a mí [traicionar los secretos políticos de Oquendo], a no haberme enamorado entonces mismo de una famosa cómica llamada Ignacia Ibáñez, la mujer de mayor talento que yo he conocido, y que tuvo la extravagancia de enamorarse de mí, cuando yo me hallaba desnudo, pobre y desgraciado. Su amable trato me alivió de mis pesadumbres; pero murió a los cuatro o cinco meses de un tabardillo muy fuerte, pronunciando mi apellido. Sus amores formarán un artículo aparte, por no interrumpir la serie de mis sucesos en casa del conde Presidente (p. 110).

«Por no interrumpir la serie de mis sucesos en casa del conde Presidente»: esa frase sirve para centrar el principio por el que organiza su material biográfico. A este respecto conviene recordar que la obra concluye con un apéndice titulado «Carácter de los principales sujetos que he tratado, con las anécdotas más notables de lo que me ha pasado con ellos» (pp. 112-113), lista de veintitrés nombres donde figuran su padre, Aranda, varios aristócratas, algunas mujeres de su vida...; en una «Nota» final avisa que «Cada carácter de los de esta lista, en hojas sueltas que forman cuadernillo separado, para no interrumpir la serie» (p. 113). Así pues, la ausencia de ciertos detalles que conceden textura a una autobiografía tiene que ver con el deseo de Cadalso de centrarse en su conflicto en casa de Aranda: selecciona este asunto como eje de su interés y desplaza a textos complementarios las ramificaciones que pueda dar de sí su vida, como esas semblanzas de personajes, o como las historias que menciona como escritas por separado y que no se conservan o no se llegaron a escribir.

La recta final de la autobiografía muestra el fondo de su caída, la miseria rigurosa en que llegó a vivir por culpa de estas desgracias y de

${ }^{35}$ «El drama de la vida de Cadalso es la amistad traicionada: la mayor prueba de su hombría de bien, que tanto preocupa a Cadalso, espíritu moralizador, estriba precisamente en su lealtad al amigo, por quien arriesga todo», EMBEITA, art. cit., p. 324. 
las enfermedades que le sobrevinieron. Cadalso se recrea en su penuria, intentado dar compasión o tal vez porque es una persona tendente a recrearse en su desdicha. Pero si llega a estos extremos es, sin duda, porque no pensaba publicar esta obra; en la mentalidad del XVIII no cabe que un militar de familia hidalga que busca un lugar preeminente en la sociedad airee en público trances tan humillantes como éstos: «pasé cuarenta y ocho horas sin más alimento que cuatro cuartos de castañas» (p. 110); «el primer día de cama lo pasé con un caldo que me dieron, como de limosna, las vecinas de la casa que vivían en un cuarto del patio y eran madre y mujer de un infeliz oficial de cerrajero» (p. 111).

El final es el punto de llegada de ese desengaño de la vida cortesana, del que, sin embargo, pronto se recuperó:

\begin{abstract}
Empezaba a urgir mi regreso al regimiento, acabada la comisión que me detenía en Madrid, sin haber merecido por ella la menor recompensa sino unos cuantos cumplidos de aquellos que son tan comunes en la boca de los ministros como insulsos en la práctica. Se trató de hacer dinero para pagar deudas y comprar camisas, hallándome tan positivamente desnudo que me iba a mudar a casa de Mr. Augé las que él me prestaba, dejándoselas alguna vez bien mojadas en mis lágrimas. Entonces compuse los Eruditos y Suplemento y publiqué mis poesías. Equipéme medianamente con su producto y me fui a instante, donde me mantengo hoy, último del año de 1773, bien desengañado de Corte, amigos y pretensiones, y entregado a los libros (pp. 111-112).
\end{abstract}

\title{
LAS ADICIONES
}

Los textos tardíos que Camarero agrupa como Apuntaciones autobiográficas son más irregulares. Existe, en primer lugar, una «Continuación desde septiembre de 1774» (pp. 113-116), donde cuenta los intentos de superar su caída en desgracia, su decisión final de dejar el ejército y algunas vicisitudes de sus Cartas marruecas, para luego informar de su reintegración al regimiento, asuntos apuntados con afán de brevedad, remitiendo de continuo a cartas recibidas o enviadas. No hay integración entre los distintos temas y más parece un diario abreviado que otra cosa.

Los otros trozos tienen un inequívoco talante burgués. Siguen una «Composición de lugar para este viaje» (p. 117), que es una lista de cosas que tiene que hacer en su inminente desplazamiento a Madrid, y unas «Consideraciones que me mueven a solicitar hacer fortuna, como de lo último se infiere» (p. 118), serie numerada de razones para sus pretensiones de medro. Ambas piezas revelan la tensión del escritor ante su futuro incierto, que le llevan a poner en el papel, como en una relación de pros y contras, los principios que han de regir su actuación en la corte para conseguir la ansiada ascensión social.

Aparece después el título «Consideraciones sobre lo que en otros me 
ha parecido medios u obstáculos para la salud», que faltan en el manuscrito. Sigue otra «Continuación» (pp. 118-121), con breves notas sobre su estancia en Madrid en 1778, una lista de sus deudas —otro pedazo de su angustia social-, su llegada a la campaña de Gibraltar (esboza un plan de acción y anuncia que más adelante lo detallará), y diversos asuntos de dicha campaña. A continuación incluye una «Noticia de las leguas que he andado por vía recta, despreciando los viajes pequeños, hasta la fecha de arriba» (pp. 121-122), que es la lista de los desplazamientos hechos durante toda su vida, señalando las distancias en leguas: es el único rastro que queda en esta autobiografía del viaje ilustrado, tan habitual en los textos personales de sus contemporáneos y de los autores posteriores. La «Continuación desde 22 de mayo de 1779» (p. 122) añade un nuevo viaje a la suma total de leguas y anota otros dos asuntos relativos a Gibraltar.

Termina con una «Nota» (p. 123), donde reaparece ese intenso sentido de la amistad que ya he analizado con motivo de Oquendo y Aranda. En esta ocasión, es el sobrino de Floridablanca, Francisco Salinas de Moñino, el causante de su reflexión; llegó a desarrollar una estrecha amistad con este joven de veinte años durante su estancia en San Roque, sitiando Gibraltar. Este pasaje demuestra que Cadalso, pese a todo, no se desengañó de comportarse como un hombre de bien y de estar a la altura de sus mejores cualidades, a pesar de creer que no le reportaban premio alguno:

[...] desordenado en mujeres y juego, pero franco, honrado, etc. En fin, vi en él los defectos que yo conocí en mí mismo y las buenas prendas que mi amor propio me hacía creer se hallaban en mi persona. Lo cierto es que su genio amabilísimo me alivió mucho de la pesadumbre que imprime una continua soledad como la que pasaba, y se fue experimentando en las causas serias que se verán en el diario reservado. Pero se cansó y lo fue dejando, sin embargo, que hice por detenerle más de lo que hubiera practicado por la protección de un Primer Ministro Supremo o por los favores de la dama más hermosa de Europa. De los pocos sujetos que he querido en el mundo (por distintos términos), este fue el único que no me quiso más de lo que yo le quise a él. Me costó una pesadumbre formal la separación; pero me determiné a ella no con pocos deseos de ver si yo era hombre capaz de vencerme a mí mismo (p. 123).

Como se ve, son textos heterogéneos, erráticos, sin coherencia interna ni continuidad. Apuntes para una futura redacción más elaborada, lo que parece claro es que, acabadas sus memorias, Cadalso mantuvo la tensión interior de desahogarse por escrito, el hábito de autobiografiarse. Seguramente, si hubiera vivido más años, hubiera acabado por redactar una crónica larga y más estructurada sobre su vida. 


\section{ALGUNAS CONCLUSIONES: MORAL, JUVENTUD Y HOMBRÍA DE BIEN}

María Embeita afirma que «la actitud íntima de Cadalso ante su vida, como se desprende del discurso autobiográfico, es la del hombre que, al hacer el balance de su vida, se siente defraudado y sospecha que erró en la trayectoria elegida» (art. cit., p. 325). Aquí hay algo capital que queda por decir: ¿el balance de qué vida?

En realidad, él apenas tiene trayectoria que evaluar, es un hombre que está comenzándolo todo. Escribe las Apuntaciones en 1773, con algo más de treinta años. Es aún joven en términos sociológicos, es decir, una persona que no ha decantado su rumbo en la vida: no ha fundado una familia ni tiene expectativas de hacerlo; sus amores con María Ignacia Ibáñez se vieron interrumpidos trágicamente; su carrera ha sido poco lucida, con escasos progresos en el ejército $\mathrm{y}$, para colmo de males, acababa de perder la amistad del conde de Aranda y se hallaba en la duda razonable de si el destino de sus días iba a ser triunfar en la milicia o hacer carrera en la corte o simplemente fracasar. En cuanto a la literatura, está en un momento creativo: en 1772 había publicado Los eruditos a la violeta, libro que le dio fama, y en 1773 su volumen poético Ocios de mi juventud; en esos mismos años escribe las Cartas Marruecas, que en 1774 trató de imprimir, sin conseguirlo. Había escrito sus Noches lúgubres y había estrenado en privado su tragedia neoclásica Don Sancho García: se estaba haciendo un nombre como escritor, pero su obra impresa era aún escasa y, en suma, comenzaba apenas a brillar en la República de las Letras, de la que, por otra parte, no sabía si podría obtener el nivel de vida y la posición social a la que aspiraba. Además, el hecho que da la pauta anímica a esta autobiografía es su violenta ruptura con el círculo del conde de Aranda y, en concreto, con su amigo Joaquín de Oquendo, por cuya deslealtad se siente ultrajado. Esa traición a la amistad es un asunto personal, pero que posee otras repercusiones: pérdida de protectores gubernamentales, ruina de las expectativas de su carrera, hundimiento en la miseria económica y, ligado a todo esto, una grave enfermedad que le postró en el lecho.

Su situación es, en todos los sentidos, opuesta a la de los otros representantes de la autobiografía moderna, a autobiógrafos como Rousseau, Saavedra, Posse, Mor de Fuentes, Llorente, Villanueva... Éstos escriben desde la ancianidad o desde una sólida madurez, cuando sus vidas están ya cumplidas en su mayor parte, con la intención de explicar, justificar o compensar su éxito o su fracaso. Todos tienen una idea precisa de ellos mismos, de su papel en la historia del país y de lo que quieren demostrar con sus autobiografías. Por esta razón, son escritos coherentes, homogéneos, elaborados tras una reposada reflexión sobre la identidad personal: son miradas hacia atrás, no de hombres que se contemplen en el espejo 
del presente, sino de hombres que más bien repasan sus retratos de niñez, de juventud y de madurez, seleccionando los rasgos que quieren mostrarnos de sus condiciones morales, de sus oficios y de sus experiencias.

Cadalso es cosa bien distinta: él expresa por medio de su angustia y su contradicción la perplejidad de una vida sin cumplir, del miedo de no llegar a ninguna parte en la política, en el ejército, en el amor, en la sociedad, en la literatura..., de no saber si su destino va a ser alguno de éstos u otro diferente. Como sugiere Suárez-Galbán, Cadalso vive la desazón interior que le causó su niñez solitaria y desarraigada y el despego de un padre ausente y sin afecto - sentimientos que, por su edad, aún vive como cercanos-, pero pienso que mucho más aún le atormenta otra desazón, la de su futuro incierto, la venenosa sospecha de que no será capaz de abrirse paso. Su frustración se proyecta hacia el futuro más que hacia el pasado. Si Deacon afirmaba en un pasaje que ya cité que «el lector se queda con la sensación de no haber conseguido conocer al auténtico Cadalso», yo pienso que en realidad la clave está en que Cadalso escribe precisamente para ver si él mismo consigue así «conocer al auténtico Cadalso».

En esto, la autobiografía juvenil de Cadalso carece de parangón en nada de lo que por entonces se hace en España, tampoco anticipa lo que viene después: ningún otro texto autobiográfico español del XVIII y de la primera mitad del XIX se le asemeja. Por eso su clasificación es ardua, tanto tipológica como cronológicamente: la primicia de un tipo de autobiografía moderna que, no obstante, cuando madure en España décadas más tarde será tan diferente - Saavedra, Posse, Mor de Fuentes, Blanco White o Moratín - que en realidad no parece la misma cosa.

Esta autobiografía tiene poco que ver con una autobiografía aventurera o militar, menos aún con una autobiografía picaresca y nada de nada con una autobiografía literaria. Es evidente que a Cadalso la guerra y la carrera castrense que ha emprendido no le interesan desde el punto de vista heroico ni desde el histórico o testimonial. Su vocación literaria tampoco es objeto de sus inquietudes. De sus hazañas galantes sólo da retazos sueltos. La familia y la niñez sólo le sugieren recuerdos escuálidos, aunque sobre ellas pesa la sombra desasosegante de un padre frío y ausente y de un desarraigo vital -y más tarde económico- que le deja abandonado a una honda soledad. De su carrera civil, de sus aspiraciones en la corte, nos da algunos datos más, pero también fragmentarios y discontinuos, moviéndose entre lo anecdótico y lo sentimental. En suma, el lector no sabe bien qué es lo que quiere contar Cadalso en estas páginas - ¿lo sabe el propio Cadalso? - ni con qué fin las escribe. No es un escritor, ni un soldado, ni un político, ni un testigo de su tiempo, ni un cronista de su vida privada, ni un agudo narrador de divertidos lances picarescos, pero sí es un poco de cada cosa en algún momento de sus Apuntaciones autobiográficas. ¿Sobre qué construye entonces su identidad? 
Cadalso busca su propia imagen en un espejo lleno de sombras y reflejos: su identidad parece sustentarse en algo muy frágil, en unos valores que casi nunca hace explícitos, pero que no son ni sus cualidades literarias ni su ardor guerrero..., ni tienen que ver con un oficio o un protagonismo cortesano, sino con una cualidad moral, la de ser hombre de bien, idea que repite una y otra vez en su autobiografía, y que es lo único que queda en pie ante el sucesivo fracaso de sus esperanzas mundanas, de las amistades a las que da tanta importancia, de sus amores, de su patrimonio y de su propia salud. Su testimonio autobiográfico - la idea que garantiza la unidad de un escrito a veces tan hecho jirones- es de naturaleza moral: por decirlo de algún modo, la suya es su autobiografía en cuanto hombre de bien maltratado por el destino.

En este punto he de volver al testimonio del propio Cadalso cuando escribe en 1775 a Meléndez, al remitirle la autobiografía junto a sus otros papeles, que haga uso de su manuscrito «para su gobierno en el mundo» (p. 103). Con esto atribuye a su obra un valor aleccionador de ejemplo moral. A estas alturas creo que ya se puede interpretar esa enigmática frase: no es una lección de moralismo retórico lo que cree proporcionar $\mathrm{Ca}$ dalso a su amigo, sino una ilustración en propia carne de lo que vale la virtud en el mundo; una ilustración que atañe a esa lúgubre melodía que hace del relato la pesimista confesión de un amargo desengaño que, en sentido laico - algunos dirían que prerromántico, otros que estoico-, es tan patente en las Apuntaciones autobiográficas.

La pregunta que queda en el aire es si Cadalso está de verdad desengañado de ser hombre de bien en un mundo donde triunfan los miserables -y entonces la lección es triste y patética - o si ofrece lo que entiende como su sacrificio personal - culminado en el holocausto de su carrera por amistad hacia Oquendo - a manera de una prueba que la vida exige a los verdaderos hombres virtuosos y que, por tanto, es un ejemplo lleno de trágica grandeza. Esto es, ¿quiere decirnos Cadalso que su bonhomía le ha arruinado, que en esta vida no hay recompensa a la virtud y que los hipócritas como Oquendo se salen con la suya? ¿O se enorgullece de poder decir que, pese a ser eso así, él no renunció ni renuncia a su ideal moral? Si nos inclinamos por la primera opción, el resultado es la desesperación; si por la segunda, se abre un camino a la esperanza, que, según Antonio Buero Vallejo, es la condición de toda auténtica tragedia ${ }^{36}$.

\footnotetext{
${ }^{36}$ «Numerosas veces he expuesto mi convicción de que el meollo de lo trágico es la esperanza. Afirmación es ésta abruptamente opuesta a la general creencia de que, mientras hay esperanza, no hay tragedia», A. BUERo VALLEJo, Tres maestros ante el público (Valle-Inclán, Velázquez, Lorca), Madrid, Alianza Editorial, 1973, p. 133. «Si tantas veces se ha identificado la tragedia con la desesperanza, no es porque la esperanza se halle ausente de ella, sino por ser la desesperanza su cara negativa, que asomará, invasoramente en ocasiones, cada vez que la esperanza surge. En esa tensión ambivalente que es, no lo
} 
La pregunta no tiene respuesta, no porque el texto sea ambiguo, sino porque Cadalso no posee todavía esa respuesta, sólo es dueño de la perplejidad de estar convencido de ser un buen hombre - un hombre de bieny a la vez creer que una triste fatalidad le persigue desde la niñez. Por eso estamos ante una autobiografía juvenil, la autobiografía de una vida llena de dudas, caminos abiertos y desengaños que, pese a todo, no se atreve a sentir como definitivos. Ésa es, a mi juicio, la rareza de Cadalso, su enigma y su diferencia respecto a las demás autobiografías españolas de su tiempo, que no tienen ni esta complejidad psicológica, ni este compromiso moral tan punzante. En este sentido se puede hablar de una autobiografía moderna, porque el hilo - levísimo a veces, vacilante casi siempreque unifica y da coherencia a este escrito es una indagación, casi un tanteo, acerca de la personalidad de su autor, del conflicto entre sus aspiraciones prácticas y los valores morales que cree poseer. Orgullo de ser hombre de bien, miedo al fracaso, frustración y duda... Cadalso escribe para sí mismo, como terapia para su confusión, pero su escritura misma es reflejo de esa confusión. La autobiografía, en suma, de un hombre moderno, amedrentado pero orgulloso, con una vida sin hacer, un impulso pasional hacia adelante siempre refrenado por el miedo y por la razón ${ }^{37}$, pero impulso al fin y al cabo, lo que es todavía más urgente para Cadalso que mirar hacia atrás.

olvidemos, dialéctica y dinámica, la des-esperanza — palabra compuesta y subordinada, simple reverso- nos remite a la esperanza como final sentido de lo trágico, aunque consista en una esperanza desesperada», ibíd., pp. 138-139.

${ }^{37}$ Francisco AgUiLAR PIÑAL, "Análisis grafológico de Cadalso», Revista de Literatura, LVII, n. ${ }^{\circ} 114$ (1995), pp. 467-476, ha realizado un curioso acercamiento por medio de la grafología; con independencia de la fiabilidad que quepa atribuir a este método en los estudios literarios - no se dice sobre qué textos ni de qué fechas se realizó el análisis grafológico-, el dictamen emitido por una especialista que, según se afirma, lo ignora todo acerca del escritor, facilita estas impresiones sobre su psicología: se muestra como un hombre que ansía el reconocimiento ajeno, pero de amor propio vulnerable y fácil de herir. «Es impresionable, inquieto y susceptible, pero carece de suficiente resistencia a la frustración. La delicadeza de sus sentimientos le hace particularmente frágil, y de ello se defiende por medio del orden, el método y una preocupación de rigor y exactitud que le permite controlar su fuerte emotividad» (p. 472, es cita literal del dictamen). 


\title{
RESUMEN
}

\section{La autobiografía juvenil de José Cadalso, por Fernando Durán López.}

La breve autobiografía de José Cadalso, escrita en 1773 y desconocida hasta su descubrimiento en 1967, ha dado lugar a interpretaciones muy diversas y contradictorias. Es una obra que posee un gran valor para caracterizar la personalidad de Cadalso y también supone un testimonio único dentro de la literatura autobiográfica en la España del siglo xviII. En el artículo se efectúa una revisión crítica de las distintas opiniones vertidas sobre este opúsculo, se estudia su estilo, su estructura, la selección del material biográfico incluido en estos recuerdos y su desarrollo. La conclusión de este estudio caracteriza la obra de Cadalso como una precoz autobiografía de estilo moderno, introspectiva y dominada por inquietudes morales y psicológicas, que se distingue de todas las otras autobiografías modernas españolas por su condición de escrito juvenil, presidido por la incertidumbre ante el futuro antes que por el balance de la vida pasada.

Palabras clave: Cadalso, Autobiografía, Literatura Española del siglo XviII.

\begin{abstract}
The brief autobiography written by José Cadalso in 1773, unknown until its discovery in 1967, has driven to some interpretations in many different and contradictory ways. This work has a great importance in order to describe Cadalso's personality, and it presuposes also an unique testimonial on the Spanish autobiographical literature of the eigteenth century. This paper aims at making a critical revision of the different readings included in that little work and try to study not only its style and structure, but also its selection of the biographical information found in the memoirs and its consecuent development. The conclusion is that Cadalso's work is an early autobiography in a modern sense, introspective and full os moral and psychological preoccupations. This autobiography takes a distance from the rest of Spanish modern autobiographies in the fact of being a work written in Cadalso's young years, in the middle of incertitudes to the future and not with the intention of making an overview of his past life.
\end{abstract}

Key words: Cadalso, Autobiography, Spanish literature in the eighteenth century. 